\title{
Effect of dietary energy source on energy balance, production, metabolic disorders and reproduction in lactating dairy cattle
}

\author{
Ariëtte T.M. VAN KNEGSEL ${ }^{a, b *}$, Henry VAN DEN BRAND ${ }^{a}$, Jan DIJKSTRA ${ }^{b}$, \\ Seerp TAMMINGA ${ }^{\text {b }}$, Bas KEMP ${ }^{\mathrm{a}}$ \\ a Adaptation Physiology Group, Wageningen Institute of Animal Sciences, Wageningen University, \\ PO Box 338, 6700 AH Wageningen, The Netherlands \\ $\mathrm{b}$ Animal Nutrition Group, Wageningen Institute of Animal Sciences, Wageningen University, \\ PO Box 338, 6700 AH Wageningen, The Netherlands
}

(Received 18 May 2005; accepted 22 June 2005)

\begin{abstract}
The pathway for oxidation of energy involves a balanced oxidation of $\mathrm{C} 2$ and $\mathrm{C} 3 \mathrm{com}$ pounds. During early lactation in dairy cattle this $\mathrm{C} 2 / \mathrm{C} 3$ ratio is out of balance, due to a high availability of lipogenic $(\mathrm{C} 2)$ products and a low availability of glycogenic $(\mathrm{C} 3)$ products relative of the $\mathrm{C} 2$ and $\mathrm{C} 3$ products required for milk production. This review compares studies which manipulated dietary energy source and shows that dietary energy source can affect the balance of the $\mathrm{C} 2 / \mathrm{C} 3$ ratio, as indicated by plasma NEFA, $\beta$-hydroxybutyrate (BHBA) and glucose levels. It is shown that glycogenic nutrients increase glucose and insulin concentrations and decrease NEFA and BHBA plasma levels. Extra lipogenic nutrients elevate NEFA and BHBA and decrease plasma glucose concentrations. Lipogenic nutrients generally increase milk fat percentage and decrease milk protein percentage, suggesting a surplus of $\mathrm{C} 2$ compounds. The inverse is the case for feeding extra glycogenic nutrients, implying reduced deamination and oxidation of glycogenic amino acids. Feeding extra glycogenic nutrients improved the energy balance (EB), in contrast to ambiguous results of lipogenic nutrients on EB. Moreover, glycogenic feed may reduce the severity of ketosis and fatty liver, but increased the incidence of (sub)clinical acidosis. Since studies are scarce, it seems difficult to draw conclusions on the effects of dietary energy source on reproduction. However, lipogenic nutrients decrease glucose and increase NEFA and BHBA plasma levels. High plasma NEFA and BHBA and low plasma glucose levels are associated with decreased reproductive performance, which might imply the $\mathrm{C} 2 / \mathrm{C} 3$ compound balance to be important for reproductive function.
\end{abstract}

lipogenic nutrients / glycogenic nutrients / reproduction / energy metabolism

\section{INTRODUCTION}

\subsection{Negative energy balance and related disorders}

Over the last several decades, intense genetic selection, improved dairy nutrition and cow management have significantly increased the milk yield of dairy cattle, in particular in the Holstein Friesian cattle breed. It is now well known that these economically favorable developments are accompanied by some negative consequences, such as an increase in the incidence of metabolic

\footnotetext{
* Corresponding author: Ariette.vanKnegsel@wur.nl
} 


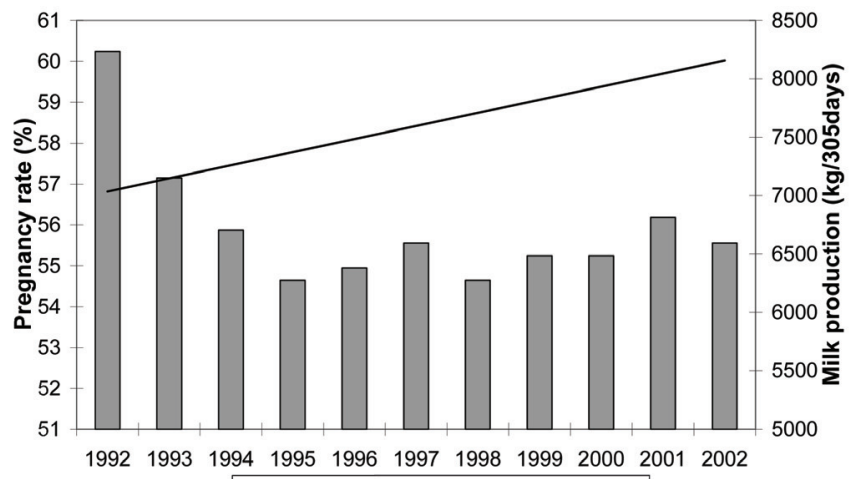

a.

$\square$ Pregnancy rate - Milk production

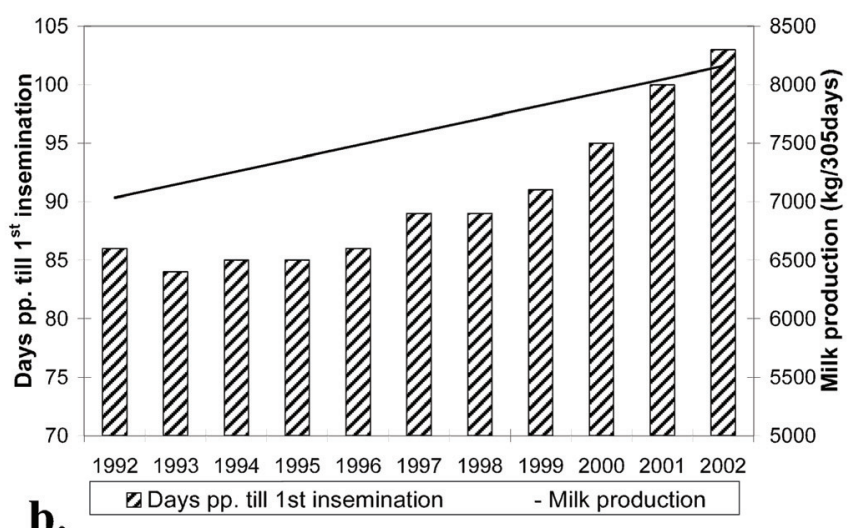

Figure 1. Pregnancy rate and annual milk production of dairy cows in The Netherlands from 19922002 (a); Interval pp till 1st insemination and annual milk production of dairy cows in The Netherlands from 1992-2002 (b). Data based on > 1 million calvings per year (adopted from [5]).

diseases and a reduction in reproductive performance [1-4], as illustrated for the pregnancy rate of dairy cattle in The Netherlands in Figure 1a (adopted from [5]). However, in The Netherlands, pregnancy rate has seemed to be stabilized from 1995 onwards. Dutch dairy farmers were able to consolidate the pregnancy rate by increasing the number of days postpartum (pp) till first artificial insemination (Fig. 1b; adopted from [5]), resulting in an increase in inter calving interval (from 393 days in 1992 to 417 days in 2002). Veerkamp et al. [6] indicated that the increase in genetic merit for feed intake did not parallel the increase in genetic merit for milk yield. They suggested that selection on high genetic merit for milk yield is only partially compensated for by an increase in feed intake resulting in an ongoing increase in negative energy balance (NEB) status during early lactation.

Energy balance (EB) can be defined as the difference of net energy intake minus net energy expenditure for maintenance and milk production. If energy expenditure is higher than intake, EB is negative [7] and cows lose body weight. Most studies on the effect of EB on reproductive performance in dairy cattle estimate the EB in the cattle from estimated dietary net energy intake 
minus an estimation of energy requirement for maintenance and minus the energy produced in milk [8-18]. Other studies use the change in body weight or body condition score (BCS) as indicators for a cow's energy status [19-21].

Several reviews have been published concerning the effect of EB status in dairy cattle on reproductive efficiency [22-35]. A status of NEB decreases LH pulse frequency, growth rate and diameter of the dominant follicle, weight of the corpus luteum (CL), peri-estrous hormone concentrations like estradiol (E2) and progesterone (P4) [11, 24, 25, 36-39]. In addition, NEB has been related to more days till the first observed estrus postpartum (pp) [12, $16,40]$, more days till first ovulation $[8,11$, $22,32]$, more days open pp [41], decreased conception rates following artificial insemination $[14,21,25,41]$ and lower pregnancy rates [15].

As recently reviewed [42], the early lactation period in dairy cattle have been clearly identified with an increased disease incidence. NEB has been indicated as an important factor involved. Epidemiological studies have related NEB directly or indirectly via milk yield to laminitis, leg problems, mastitis and metabolic disorders like ketosis, ruminal acidosis and displaced abomasum [43-45].

\subsection{Energy metabolism in high-producing dairy cattle}

Metabolism has been recognized to supply the intermediate signals in the relations between NEB and reproduction or health status in dairy cattle. Figure 2a (adopted from [46]) illustrates the pathway of substrates used for energy metabolism in nonlactating dairy cattle. The dietary ingredients fiber, carbohydrates and protein provide substrates for ruminal fermentation and result in the ruminal production of volatile fatty acids (VFA). The main VFA produced are acetate and butyrate, which are or can split up into fragments containing two carbon atoms (C2) (lipogenic), and propionate, which is a fragment containing three carbon atoms (C3) (glycogenic). Rumen resistant dietary ingredients and microbial matter can be digested and absorbed in the intestine and provide either $\mathrm{C} 2$ or $\mathrm{C} 3 \mathrm{com}$ pounds. The final common pathway for oxidation involves the oxidation of a $\mathrm{C} 2$ (acetyl-coenzyme-A) and a C3 (oxaloacetate) fragment to form citrate in a molecular ratio 1:1. Citrate proceeds through a series of intermediate reactions of the Krebs cycle to make ATP, NADH and $\mathrm{FADH}_{2}$ available. NADH and $\mathrm{FADH}_{2}$ can react with oxygen to produce energy for the body as ATP (respiratory chain reaction). In addition, Figure $2 b$ shows that dairy cattle in early lactation usually have a limited dry matter intake and are therefore in a negative energy balance. This results in the mobilization of body reserves. Mobilized body reserves are mostly body fat (mainly $\mathrm{C} 2$ compounds) and to a lesser extent body protein (partly C2, partly C3 compounds). Mobilization of body fat results in elevated blood NEFA levels, which can be oxidized to AcetylCoA or stored in the liver as tri-acyl glycerol (TAG), possibly causing fatty liver. The high milk production in early lactation requires a high lactose production (from $\mathrm{C} 3$ compounds) which results in decreased glucose and insulin levels. The production of Acetyl-CoA from acetate, butyrate and fatty acids from body reserves is high whilst at the same time C3 compounds from glucose and glucogenic precursors, including glucogenic amino acids, are driven towards lactose. Consequently, the ratio of oxaloacetate to acetyl-CoA is out of balance. The availability of citrate to form ATP in the Krebs cycle is decreased. Acetyl-CoA is diverted to the production of ketone bodies, acetone, acetoacetate and $\beta$-hydroxybutyrate (BHBA), resulting in a status of ketosis.

In summary, the metabolic effects of an NEB are an imbalance in $\mathrm{C} 2 / \mathrm{C} 3$ nutrient ratio and low plasma glucose and insulin concentrations and high concentrations of plasma NEFA, BHBA, acetone, acetoacetate and liver TAG. 


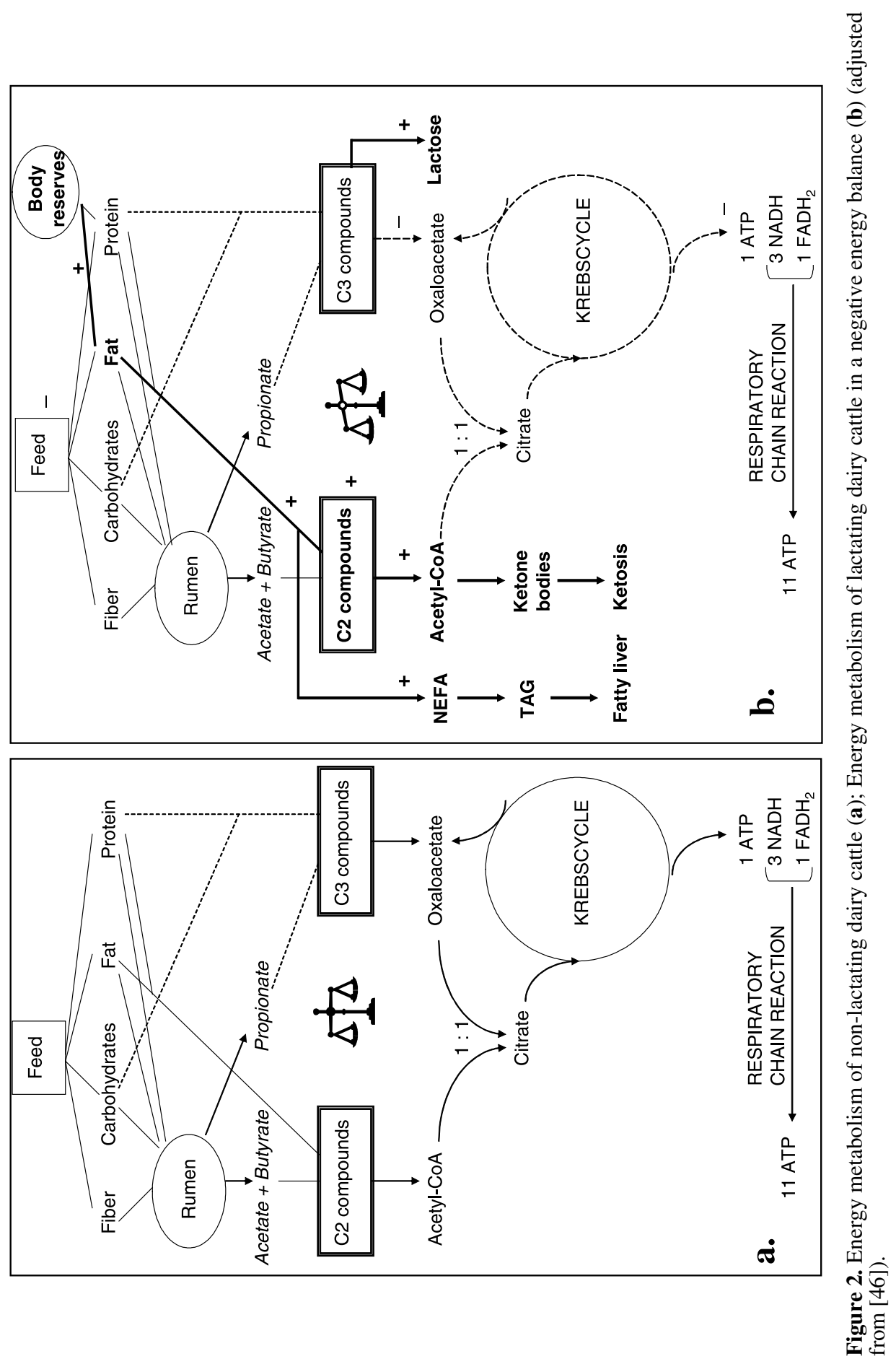


Several reviews have indicated nutrition to be important in the prevention and treatment of NEB related disorders [25, 47-54]. The relation of NEB with protein metabolism has been reviewed [25, 47], just as the relation between dietary fat (C2 compounds or lipogenic) and metabolic and reproductive disorders [48, 51, 54-56]. However, the key problem that occurs in the metabolism of a dairy cow in early lactation seems to be the unbalanced availability of C3 (glycogenic) and C2 (lipogenic) compounds derived from nutrients and body reserves.

The $\mathrm{C} 2 / \mathrm{C} 3$ compound ratio can be manipulated by ingredients in the diet. Lipogenic dietary ingredients, like dietary fat or forages that stimulate the ruminal production of acetate and butyrate, are expected to increase the $\mathrm{C} 2 / \mathrm{C} 3$ compound ratio. Glycogenic nutrients are either ruminal fermented and result in the production of propionate or are intestinal digested and absorbed as glucose. Consequently, glycogenic nutrients like grain, nonfiber carbohydrates or propylene glycol are expected to decrease the C2/C3 compound ratio.

The scope of this review is to find evidence implying the possibilities to modify the $\mathrm{C} 2 / \mathrm{C} 3$ ratio by dietary ingredients, measured by altered blood parameters that indicate the EB status and to find evidence that indicates that a more glycogenic or lipogenic diet affects metabolic disorders, milk production, energy balance and reproductive function.

\section{DIETARY ENERGY SOURCE RELATED TO BLOOD METABOLITES, METABOLIC HORMONES AND METABOLIC DISORDERS}

\subsection{Effect of lipogenic and glycogenic nutrients on blood metabolites and metabolic hormones}

Plasma NEFA and BHBA levels are recognized as indicators for body fat mobili- zation and NEB in dairy cattle in early lactation [22, 48, 55, 57]. Decreased plasma glucose and insulin levels have been associated with NEB $[12,13,57,58]$ and increase as cows progress towards a more positive EB [59]. Table I shows reported effects of feeding either extra glycogenic or lipogenic nutrients on plasma NEFA, BHBA, glucose, insulin and growth hormone $(\mathrm{GH})$ levels. Concerning plasma NEFA levels, 13 [9, 60-68] out of 15 studies found an increase after feeding extra lipogenic nutrients. In contrast to studies where extra glycogenic nutrients were fed, 13 [60, 61, 66, 68-73] out of 14 reported studies found a decrease in plasma NEFA levels. Plasma BHBA levels increased after feeding extra lipogenic nutrients in five out of eight studies $[68,69,74,75]$. Extra glycogenic nutrients were related to a decrease in plasma BHBA levels in eight out of nine reported studies [61, 69, 70, 72, 74, 76]. Plasma glucose (10 out of 13 studies) and insulin (6 out of 9 studies) concentrations were decreased after feeding extra lipogenic nutrients and in almost all cases increased after feeding extra glycogenic nutrients (glucose 13 out of 14 studies; insulin 7 out of 8 studies) [8, 9, 60, 61, 64, 66-68, 70-72, 74, 76, 77]. Plasma GH concentration was increased in most studies (4 out of 6 studies) after feeding extra lipogenic nutrients [8, 9, 61, 64]. In contrast to a decrease after feeding extra glycogenic nutrients in 5 out of 6 studies $[61,70,71]$.

In addition, liver triglyceride [78], and plasma triglyceride [66] concentrations were elevated after feeding extra lipogenic nutrients, in contrast to a study that found a decrease in liver triglyceride after feeding more non-fermentable carbohydrates [72] and studies that reported a decrease in plasma triglyceride levels after abomasal glucose infusion $[66,73]$. Two studies found a positive effect of feeding extra glycogenic nutrients on liver glycogen content [70,72], as a representative of stored carbohydrates.

Apart from an increase due to higher dietary fat content $[69,74,75]$, plasma BHBA 
Table I. Responses in metabolites and metabolic hormones to either extra lipogenic ${ }^{\mathrm{a}}$ or glycogenic ${ }^{\mathrm{b}}$ nutrients in dairy cattle based on means per treatment group.

\begin{tabular}{|c|c|c|c|c|}
\hline \multirow{2}{*}{ Category } & \multicolumn{3}{|c|}{ Responses (based on means per treatment group) } & \multirow{2}{*}{$\begin{array}{c}\text { Total No. of } \\
\text { animals compared }\end{array}$} \\
\hline & Rise & No response & Decline & \\
\hline \multicolumn{5}{|l|}{ NEFA } \\
\hline Lipogenic nutrients & 12 & 0 & 3 & 394 \\
\hline Glycogenic nutrients & 1 & 0 & 13 & 165 \\
\hline \multicolumn{5}{|l|}{ BHBA } \\
\hline Lipogenic nutrients & 5 & 2 & 1 & 144 \\
\hline Glycogenic nutrients & 0 & 5 & 5 & 106 \\
\hline \multicolumn{5}{|l|}{ Glucose } \\
\hline Lipogenic nutrients & 3 & 0 & 10 & 229 \\
\hline Glycogenic nutrients & 13 & 0 & 1 & 167 \\
\hline \multicolumn{5}{|l|}{ Insulin } \\
\hline Lipogenic nutrients & 3 & 0 & 6 & 194 \\
\hline Glycogenic nutrients & 9 & 0 & 1 & 167 \\
\hline \multicolumn{5}{|l|}{ GH } \\
\hline Lipogenic nutrients & 4 & 1 & 1 & 156 \\
\hline Glycogenic nutrients & 0 & 1 & 5 & 44 \\
\hline
\end{tabular}

${ }^{a}$ Lipogenic nutrients: prilled fat, CaLCFA, tallow.

${ }^{b}$ Glycogenic nutrients: grain, concentrates, starch, nonfiber carbohydrates, propylene glycol, glucose infusion.

Based on lipogenic nutrients: [8, 9, 60-67, 69, 74, 75]; glycogenic nutrients: [60, 61, 66, 68-74, 76, 77].

were also elevated with increasing dietary forage level [75]. Ruppert et al. [68] found no increase in BHBA, as an indicator of NEB, when fat was added to a corn silage diet, in contrast to an alfalfa silage diet. Since corn silage is mainly glycogenic (a high proportion of C3 nutrients) and alfalfa silage is mainly lipogenic (a high proportion of $\mathrm{C} 2$ nutrients), it seems logical that BHBA levels on a corn silage diet, are less increased than BHBA levels in cows on an alfalfa silage diet upon fat addition. In the corn silage diet the extra $\mathrm{C} 2$ nutrients of the fat addition are easier to metabolize because of the higher availability of $\mathrm{C} 3$ nutrients, compared to the alfalfa silage diet. It seems that the effect of dietary fat addition depends on the nature of other nutrients in the diet, suggesting the $\mathrm{C} 2 / \mathrm{C} 3$ balance to be a factor in the concentration of plasma BHBA.

The considerable variation in effects of fat supplementation on metabolites and metabolic hormones may be explained by saturation of the fat source, as indicated by Thomas et al. [79]. In this study, a positive effect on insulin and IGF-1 levels was found for poly-unsaturated fat with mainly 16- and 18-carbon fatty acids (soybean oil) compared to the control, saturated (animal tallow) and highly polyunsaturated fat with considerable $>20$-carbon fatty acids (fish oil). This was possibly caused by a difference in ruminal fermentation patterns between the fat sources since the poly-unsaturated fat treatment was expected to modify the rumen fermentation pattern in favor of propionic acid production. Moreover, digestibility of fat in the intestine depends on chain length and saturation. In general, fatty acids with more than 18-carbon atoms have a reduced digestibility whilst digestibility appears to be higher for unsaturated than saturated fatty acids [80]. Thus, a variation in the type of fat source added may increase 
variation in the effects on metabolites because of a variation in the amount of extra metabolizable energy obtained.

Santos et al. [81] reported lower NEFA concentrations and higher glucose and insulin levels in cows fed steam-flaked sorghum compared to steam-rolled corn. This can be explained by a higher ruminal starch digestibility, and resulting higher ruminal propionate secretion, of steam-flaked sorghum compared to steam-rolled corn. This is in line with Simas et al. [82] who found elevated blood glucose levels in cows fed steam-flaked sorghum, compared to dryrolled sorghum, which has a lower ruminal starch degradability. A study on starch infusion reported a difference in effect on plasma metabolite levels between infusion sites. Abomasal starch infusion tended to decrease plasma NEFA levels more than ruminal infusion. This is probably caused by the production of the VFA propionate, butyrate and acetate from ruminally infused starch, while infused abomasal starch is intestinally digested and absorbed as glucose [70].

In addition, several studies presented a diurnal rhythm for glucose, insulin, NEFA and BHBA in ruminants [83-85]. Especially, plasma NEFA levels seem to be more sensitive and variable before feeding compared to after feeding. This implies a time-of-day or a time-after-feeding effect when interpreting dietary effects on blood metabolites and metabolic hormones.

In conclusion, feeding extra lipogenic nutrients generally increases NEFA, BHBA and GH levels and decreases plasma glucose and insulin levels. Increased availability of glycogenic nutrients, e.g. dietary corn, starch infusion or propylene glycol increases plasma glucose and insulin levels, and decreases plasma GH, NEFA and BHBA concentrations. This shows that indicators for an imbalance in the $\mathrm{C} 2 / \mathrm{C} 3$ ratio can be effectively manipulated by dietary energy source. The effect of the manipulation seems to be dependent on the availability of the energy source as a metabolic C2 or C3 compound. Secondly, the effect of manipulation also seems to depend on the balance between $\mathrm{C} 2$ and $\mathrm{C} 3$ compounds, in the rest of the diet.

\subsection{Effect of lipogenic and glycogenic nutrients on metabolic disorders}

As reviewed earlier [86, 87], increasing the availability of glycogenic nutrients, in particular of readily fermentable carbohydrates in the rumen, results in an increased incidence of both clinical $(\mathrm{pH}<5.0)$ and subclinical $(\mathrm{pH}<5.5)$ acidosis. This observation is confirmed by later studies on replacing alfalfa silage with corn silage [68] or replacing a high-fat concentrate with a high-starch concentrate [88], where in both cases the ruminal $\mathrm{pH}$ decreased with increasing availability of glycogenic nutrients compared to lipogenic nutrients. With subclinical or clinical acidosis, the ruminal tissue wall may become damaged and reduced intake, digestion, laminitis and liver anomalies can occur. Thus, the level as well as the type of glucogenic nutrients (rapidly versus slowly fermentable carbohydrates) influence the occurrence of (sub)clinical acidosis and this contributes to the observed variability in the effect of glucogenic supplements on production, energy balance and reproductive characteristics.

Grummer and Carroll [56] have suggested in their review that long-term fat supplementation might cause fatty liver via chronic elevation of plasma NEFA levels. This theory is supported by firstly other studies that found a positive relationship between elevated NEFA, decreased glucose levels and the incidence of fatty liver [58, 59, 89]; secondly, evidence that indicates the relationship between liver triglyceride content and plasma NEFA concentrations [59]; and thirdly, associations between dietary fat supplementation and elevated plasma NEFA levels [9, 63].

Several studies have found a decreasing effect of glycogenic feed on plasma NEFA, BHBA and triglyceride levels [60, 72, 90], also suggesting that glycogenic feed may 


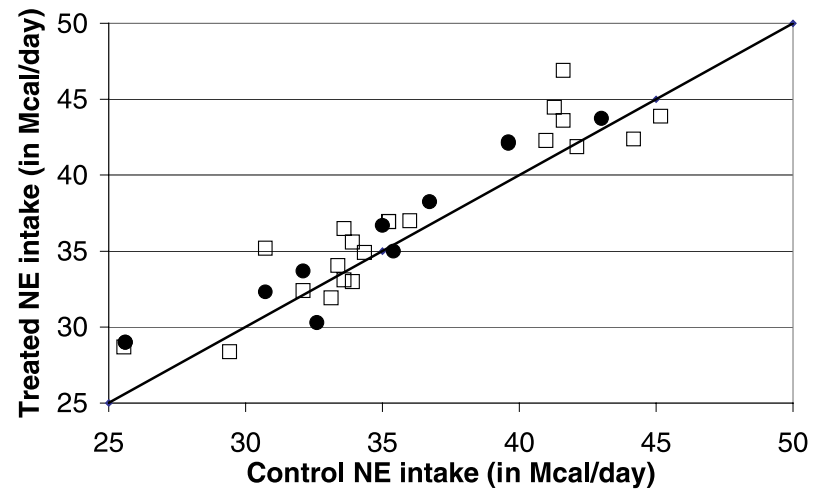

Figure 3. Effect of feeding supplemental lipogenic $(\square)$ or glycogenic $(\bullet)$ nutrients on net energy (NE) intake in Mcal per day. Points are based on means per treatment group. Points below the diagonal line represent studies with a negative effect of diet treatment, points above the diagonal line represent studies with a positive effect of diet treatment. Based on $[15,60,61,64,65,69-72,75$, 78, 99-101, 103, 104, 107, 112, 139].

reduce the incidence and severity of ketosis and fatty liver. Grummer et al. [91] supposed propionate, as a product of rumen degradable glycogenic feed, to be antiketogenic and advised to maximize hepatic glycogen stores to decrease the triglyceride/ glycogen ratio in the liver, which has been indicated as a risk factor for fatty liver and ketosis.

In ketosis-induced cattle, by feed restriction plus 1,3-butanediol, Veenhuizen et al. [58] reported that triglyceride infiltration in the liver increases and liver glycogen content decreases as cows progress towards clinical ketosis. Kronfeld [92] reviewed that the supply of lipogenic precursors for milk production relative to glycogenic precursors in the diet determines the susceptibility of cows to spontaneous ketosis; liver triglyceride to glycogen ratio indicates the relative supply of these nutrients [55]. In addition, both Grummer [55] and Drackley [93] suggest in their reviews that the occurrence of fatty liver may also have a direct effect on carbohydrate metabolism by an impaired gluconeogenesis in the liver, resulting in an increased susceptibility to ketosis.

In vitro, high levels of ketone bodies have a negative effect on the chemotactic [94] and proliferative [95, 96] capacity of lymphocytes and the secretion of immunoglobulins by lymphocytes [94-97] has been identified. In vivo, BHBA levels have been positively related to the severity of mastitis as indicated by bacterial counts [98]. Such data indicate that ketosis may negatively affect some aspects of the immune system.

High plasma NEFA and BHBA levels and low glucose levels have been related to fatty liver and a status of ketosis [55, 91]. Lipogenic and glycogenic nutrients have an effect on ruminal $\mathrm{pH}$ and the NEFA, BHBA, glucose and liver triglyceride metabolite contents. As a result, it can be expected that the incidence and severity of fatty liver and ketosis as well as acidosis is affected by the lipogenic/glycogenic nutrient ratio. This indicates the $\mathrm{C} 2 / \mathrm{C} 3$ nutrient balance to be an important element in the reduction of metabolic disorders in dairy cattle in early lactation, as shown in Figure 2.

\section{DIETARY ENERGY SOURCE \\ RELATED TO MILK PRODUCTION AND EB}

The selection of the experiments presented in Figures 3, 4 and 5 is based on the criteria: dietary treatment (extra lipogenic 


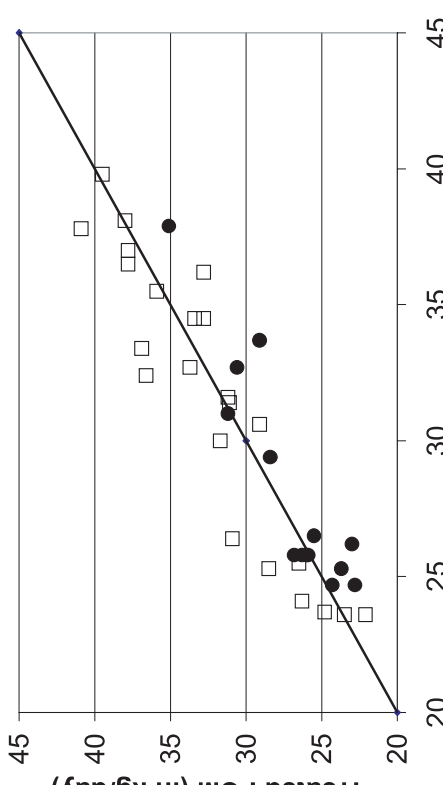

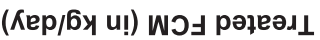

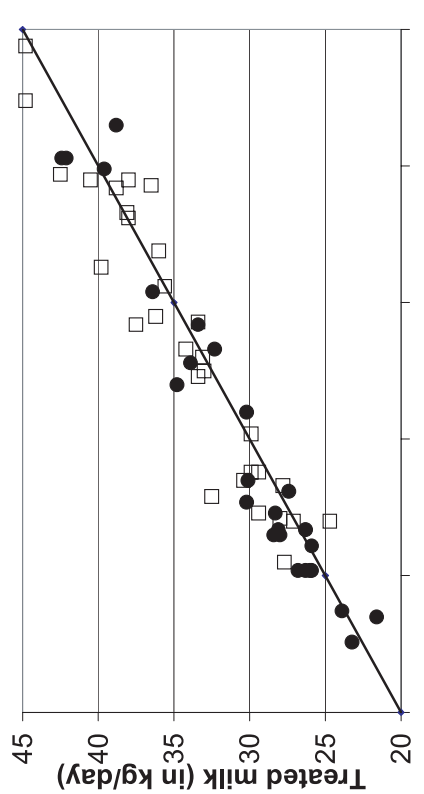

$\stackrel{8}{\forall}$

ㅇำ

ช

을

$\frac{\pi}{0}$

鸢

유 $\frac{2}{0}$

$\stackrel{n}{2}$

ก

ர்
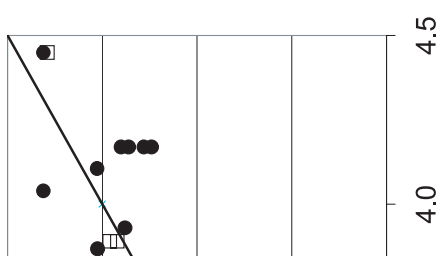

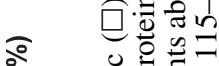

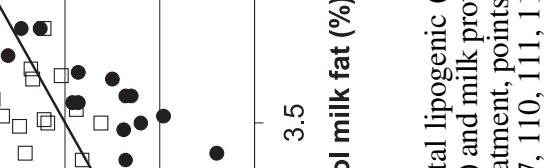

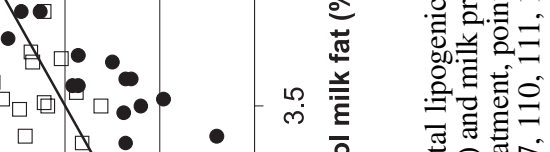

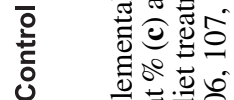

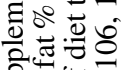

की

छิ์

\&

$4 \sum_{0}$

迁

武放 


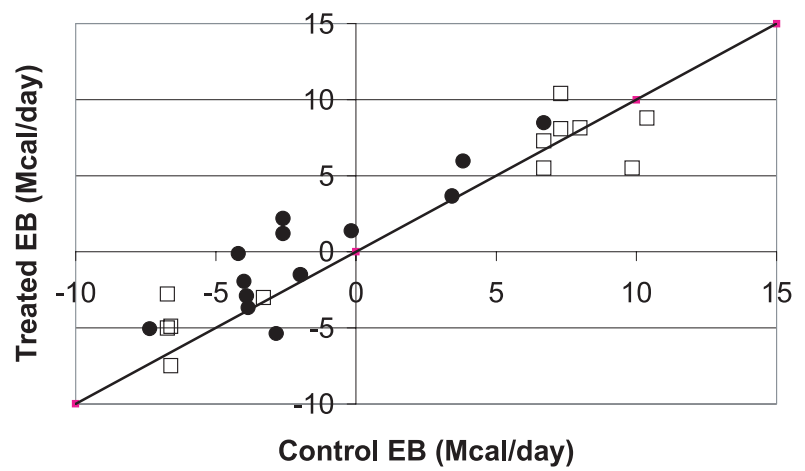

Figure 5. Effect of feeding supplemental lipogenic $(\square)$ or glycogenic $(\bullet)$ nutrients on EB. Points are based on means per treatment group. Points below the diagonal line represent studies with a negative effect of diet treatment, points above the diagonal line represent studies with a positive effect of diet treatment. Based on $[8,9,15,64,66,69,71,72,77,99,106-108,110,112,116,120]$.

and/or glycogenic nutrients fed in the treatment group) and presence of mainly multiparous lactating dairy cattle. Table II in the appendix shows the dietary treatment, No. of cows, parity and DMI of the experiments presented in Figures 3 to 6.

\subsection{Effect of lipogenic and glycogenic nutrients on energy intake}

As shown in Appendix, most studies on altering the glycogenic/lipogenic nutrient ratio, also alter the energy content of the experimental diets. On the contrary, 22 out of 31 studies $[8,9,15,60,61,63-65,67,68$, $78,82,99-107]$ reported a decrease in DMI after feeding extra lipogenic nutrients compared to 7 out of 14 studies [60, 61, 68, 72, $77,78,108-116]$ on extra glycogenic nutrients which showed a decrease in DMI in the treatment group. In general, the negative effect of extra lipogenic sources on dry matter intake is higher when the degree of saturation of fatty acids is lower, probably because of the more pronounced negative effects of unsaturated fatty acids on rumen carbohydrate fermentation. As a result, $73 \%$ of the studies on feeding extra lipogenic nutrients $[15,61,63,65,75,100,101$, $104,106]$ and also $73 \%$ of the studies on increasing dietary glycogenic nutrients [61,
69-72, 117] obtained a higher net energy (NE) intake in the treatment group compared to the control group, illustrated by Figure 3.

\subsection{Effect of lipogenic and glycogenic nutrients on milk production}

Figure 4 shows an overview of studies that reported milk yield and composition after feeding either more glycogenic nutrients or lipogenic nutrients. Both feeding extra lipogenic nutrients or glycogenic nutrients had similar effects on $\mathrm{kg}$ of milk produced per day $[8,15,60-72,75,77,78,82,99-$ 104, 106, 107, 110, 111, 115-122]. Milk fat percentage was usually elevated after feeding extra lipogenic nutrients ( 24 out of 32 studies) $[15,60-65,67,68,75,82,99-104$, $106,121,122]$, but it decreased after the addition of glycogenic nutrients to the diet (23 out of 26 studies) [60, 61, 66, 68-72, 78, 107, 110-113, 115-117, 120]. In most cases, milk protein percentage decreased after feeding extra lipogenic nutrients (23 out of 28 studies) [15, 60-63, 65, 67, 68, 75, 82, 99-104, 121]. However, extra glycogenic nutrients increased milk protein percentage in 18 out of 25 studies [ $60,61,66,68-72$, 77, 78, 107, 110, 112, 115-117, 120]. Concerning fat corrected milk (FCM), 

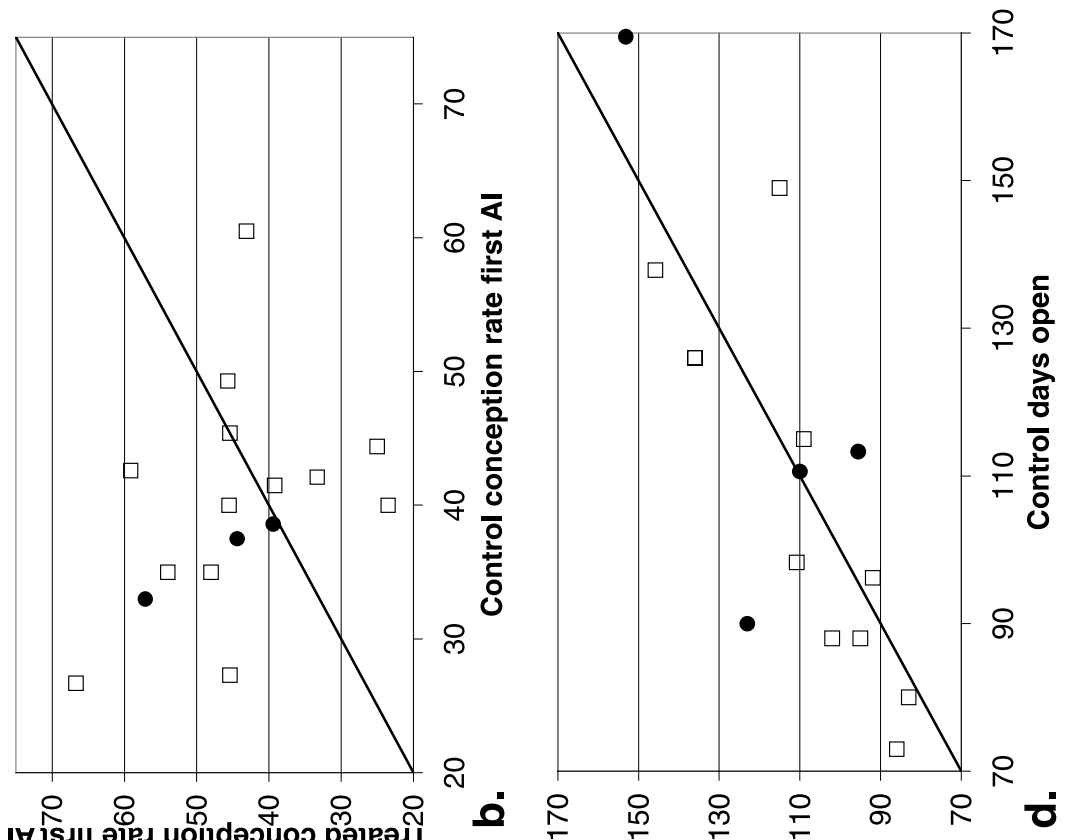

哥

요

웅
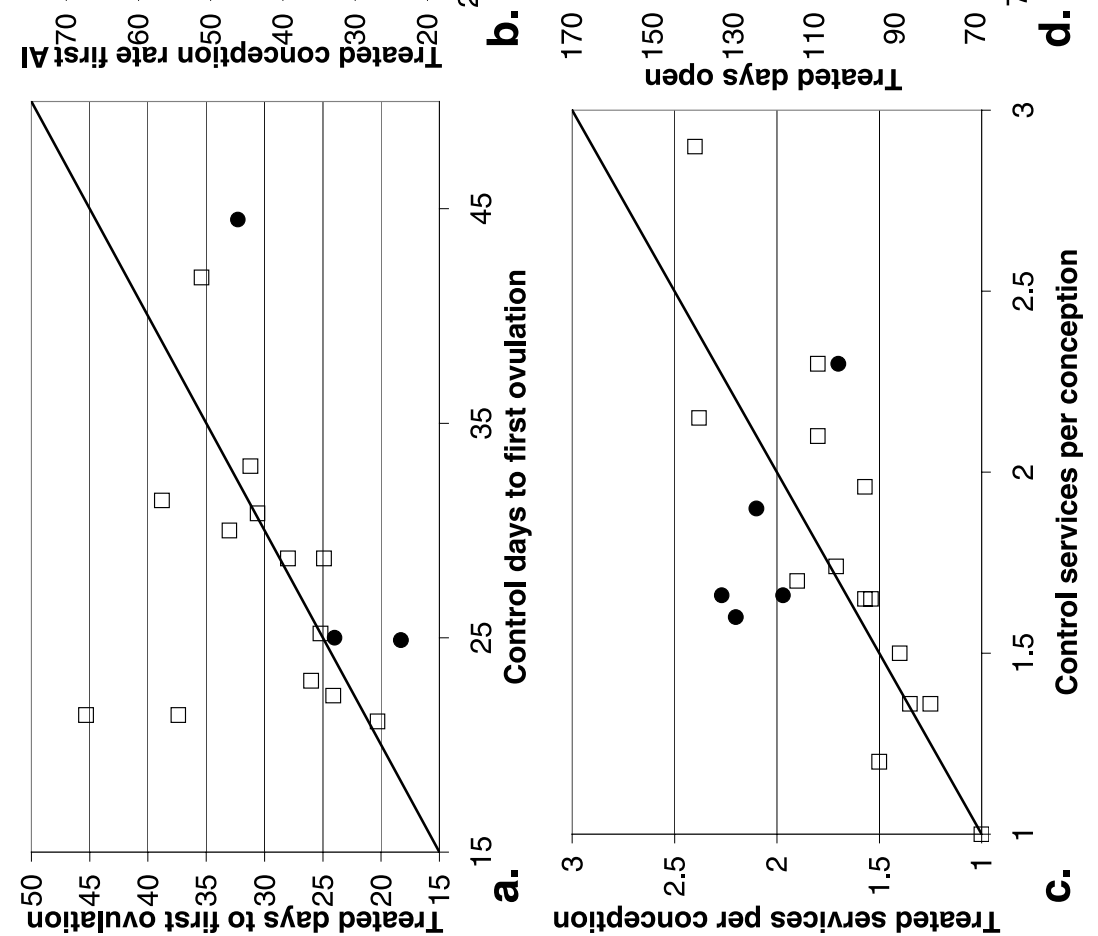

ᄃ

决

可证

ठ․

ま

N

\&

ब

o

on

政.

प

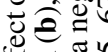

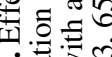


lipogenic nutrients had a positive effect on FCM in 13 out of 23 studies [8, 15, 61-65, 68, 75, 82, 99-101, 104]. After feeding extra glycogenic nutrients, FCM decreased in nine of the 14 studies $[61,66,68,69,71$, $77,78,111,115]$.

\subsection{Effect of lipogenic and glycogenic nutrients on EB}

The increased NE intake after feeding extra lipogenic nutrients, accompanied by an increase in milk fat percentage, suggests that the gained NE intake by feeding of lipogenic nutrients is probably beneficial to milk fat percentage and not to EB. This observation is supported by studies that found an increased body weight loss [9, 105] and body condition score loss [123] or a more negative EB [15] after dietary fat supplementation. Son et al. [15] even reported in a study on increased milk yield, an increased milk fat percentage, but lower NE intake after dietary fat supplementation. This suggests more body fat mobilization in the fat supplemented group than in the control group. Concerning milk composition, the inverse effect of feeding extra lipogenic nutrients is observed in a majority of the studies on feeding extra glycogenic nutrients. In a majority of the studies on feeding extra glycogenic nutrients, milk fat percentage is decreased and milk protein percentage increased. This can imply that proteins are saved from use as a glycogenic energy source after feeding extra glycogenic nutrients, indicated by the increased milk protein percentage. Figure 5 further supports these hypotheses, by presenting 18 studies on either feeding more lipogenic or glycogenic nutrients on the calculated EB. Eight of the 12 studies reported an increase in EB after feeding extra lipogenic nutrients $[8,9,12$, $15,64,66,106]$. In contrast to feeding extra glycogenic nutrients where 12 out of 13 studies were able to improve, not-significantly, the calculated EB $[66,69,71,72,77$, 107, 108, 110, 112, 116, 120].

In conclusion, extra lipogenic nutrients had variable results on EB and increased milk yield and milk fat percentage. This suggests a surplus of $\mathrm{C} 2$ compounds in the C2/C3 balance, resulting in elevated milk fat output. In contrast, glycogenic nutrients seem to increase the EB, decrease the milk fat percentage and increase the milk protein percentage, implying a more balanced $\mathrm{C} 2$ / $\mathrm{C} 3$ ratio and therefore a protein-saving effect of glycogenic nutrients.

\section{DIETARY ENERGY SOURCE RELATED TO REPRODUCTION}

The selection of the experiments presented in Figure 6 is based on the following criteria: dietary treatment (extra lipogenic and/or glycogenic nutrients fed in the treatment group) and the presence of mainly multiparous lactating dairy cattle. Table II in the appendix shows the dietary treatment, No. of cows, parity and DMI of the experiments presented in Figure 6.

\subsection{Effect of lipogenic and glycogenic nutrients on reproductive efficiency}

Figure 6 illustrates the effects of feeding supplemental lipogenic or glycogenic nutrients on days to first ovulation, conception rate following first insemination, services per conception and number of days open. Increasing glycogenic nutrients was reached by supplying extra dietary starch [118], maize gluten [109, 124], ground shelled corn [109, 124], abomasal glucose infusion [66] or propylene glycol supplementation [77]. Days postpartum (pp) till first ovulation $[66,77,109,114]$ are reported to be reduced after feeding extra glycogenic nutrients in three out of four studies. Six out of 12 studies [8, 9, 15, 63, 66, 105, 106, 109, 125] on feeding extra lipogenic nutrients reported an increase, four a decrease $[8,15$, $63,66]$ and two found $[15,63]$ no effect on days pp. till first ovulation. Conception rate following first insemination is increased after supplemental glycogenic nutrients in both reported studies [77, 118]. Six out of 
14 studies showed an increase in conception rate following first insemination by increasing the lipogenic nutrient proportion in the diet $[15,62,63,65,104,105,121$, $122,125,126]$. Number of services per conception is increased in four $[118,124]$ out of five studies on feeding extra glycogenic nutrients. Only Miyoshi et al. [77, 118] found the number of services per conception to be reduced after propylene glycol supplementation. A majority of the studies (11 out of 15 studies) [62, 65, 101, 102, 105, $114,121,122,125,126]$ reported a decrease in services per conception after the addition of lipogenic nutrients. The number of days open are reported to be reduced by glycogenic nutrient supplementation in two out of three studies [77, 118]. A few studies ( 3 out of 10 studies) [62, 63, 65, 67, 101, 102, 105, 126] showed a decrease in the number of days open after fat addition to the diet.

In addition, several studies found increased pregnancy rates $[15,62,63,122$, 127], elevated plasma progesterone ( $\mathrm{P} 4)$ level $[15,62,63,105]$, increased diameters of preovulatory follicles [64] and greater follicular populations [127-129] after dietary fat supplementation. However, other groups detected a negative relation between dietary fat addition and follicular development [9], pregnancy rates [65, 104, 125] or plasma P4 concentration [64].

Figure 6 confirms the conclusion of Staples et al. [54] that the effects of dietary prilled fat on reproductive performance are variable. In addition, Figure 6 shows that feeding extra glycogenic nutrients has variable effects on reproductive parameters as well. Several factors contribute to the diversity in effects of supplemental lipogenic and glycogenic nutrients on fertility in dairy cattle. First, as discussed before, the type of lipogenic nutrients (chain length and degree of saturation of long chain fatty acids) as well as the type of glycogenic nutrients (rate of fermentation in the rumen) affects the profile of nutrients absorbed from the gastro-intestinal tract which in turn may impact on reproductive parameters. For supple- mental lipogenic nutrients, a possible role for fatty acid composition has been suggested and confirmed in several studies [79, 130]. Petit et al. [79, 130] found a difference in conception rate after first insemination and plasma P4 levels between cows fed extracted flaxseed meal (MEGALAC) or whole flaxseed (FLAX). They suggested, next to an increased DM intake, a lower daily milk production and a less negative NEB; also the increased concentration of linolenic acid in FLAX could be beneficial by increasing progesterone levels, decreasing prostaglandin levels and consequently increasing conception rate. They discussed the potential inhibition of prostaglandin secretion by absorbed linolenic acid, as supported by the increased milk progesterone concentration in cows fed FLAX. In addition, another study [79] found an enhancing effect of poly-unsaturated fatty acids on plasma insulin level and number of follicles compared to a control group and groups fed saturated or highly poly-unsaturated fatty acids. Similarly, the variation in type of glycogenic nutrients contributes to the observed variation in effects on reproduction. Santos et al. [81] observed a non-significant increase in luteal activity and P4 levels in cows on a diet high in rumen degradable starch (RDS), compared to a rumen resistant starch diet. The authors suggested the increased EB of the RDS group to be an explanation for this observation. Additionally, also the reported increase in insulin concentrations with the RDS treatment, probably resulting from an increased production of ruminal propionate, can be beneficial to ovarian function. Secondly, it is important to differentiate between isocaloric and non-isocaloric diets, since dietary energy density has been reported to have significant effects on reproductive performance [26, 131]. As illustrated in Figure 4, most studies increased the NE intake by adding more lipogenic or glycogenic nutrients to the diet. To study the effect of dietary energy source, it is highly favorable to offer isocaloric diets to prevent this interaction with dietary energy density. Thirdly, as shown in Figure 5, several authors 
found an effect of glycogenic or lipogenic nutrients on the (calculated) EB [72, 77] which might interact with the effect of energy source on reproduction.

Concerning the above-mentioned explanations, they all also, have, besides an effect on reproductive performance, an effect on EB. This suggests that the effect of dietary energy source is not necessarily a direct effect of energy source availability, but might be an indirect effect via alterations of EB status by dietary energy source. This implies EB to be an intermediary in the effect of dietary energy source on reproductive performance.

A fourth consideration, concerning the interpretation of the effects of dietary energy source on reproductive parameters, is that parameters such as the number of services per conception or conception rate at first AI could largely depend on the protocol of the experiment. The minimum number of days until first AI seems particularly important in this aspect. A part of the presented studies in Figure $4 b$ do not specify the determination of timing of AI [65, 118, 119, 121]. Most studies applied a waiting period till first AI ranging from 39 to 90 DIM [15, 62, $105,126]$, other studies inseminated the cows after synchronization with a prostaglandin analogue [104, 132].

A fifth explanation can be that several authors suggested that optimum nutritional conditions for follicle growth are not necessarily recognized as optimum conditions for embryo-survival [52]. Exact knowledge about this hypothesis is lacking; however, it has been indicated that impaired body condition and prolonged low energy intake are detrimental to fertility. In contrast, shortterm restrictions in dietary energy intake have been shown to increase subsequent pregnancy rates in heifers [133]. Explanations can probably be found in intermediate metabolic signals. Increased energy status is related to increased plasma insulin concentration $[66,77]$ which is beneficial to follicular development [50]. On the contrary, body fat mobilization, resulting from feed restrictions, is associated with increased plasma P4 levels [133, 134], probably caused by the steroid-storage function of fat tissues, which can be beneficial to pregnancy establishment and fertility.

In summary, it is difficult to draw conclusions on the effects of feeding either extra lipogenic or glycogenic nutrients on reproductive parameters. Firstly, reported effects seem to be variable due to the type of lipogenic or glycogenic nutrients and NE intake level effects on EB. Secondly, research on the relation between glycogenic nutrient addition and EB and reproductive parameters is desirable since studies on this subject are still scarce. Some suggestions can be made since glucose and insulin are increased after feeding extra glycogenic nutrients and are suggested as positive metabolic signals to the reproductive axis [11, $13,19,57,118,135]$. Plasma NEFA and BHBA levels are increased after feeding extra lipogenic nutrients and associated with decreased reproductive performance and anestrous [9, 65, 136-138]. Both observations might imply that the $\mathrm{C} 2 / \mathrm{C} 3 \mathrm{com}$ pound balance is important for reproductive performance.

\section{CONCLUSION}

Dietary energy source affects the balance in $\mathrm{C} 2$ and $\mathrm{C} 3$ compound availability, as supplied by dietary ingredients and adipose tissue mobilization. Alterations in $\mathrm{C} 2$ and $\mathrm{C} 3$ compound availability result in modifications in blood metabolic profiles and production performance in lactating dairy cattle. These observations, together with the described effects of the $\mathrm{C} 2 / \mathrm{C} 3$ compound ratio on energy balance and reproductive performance in dairy cattle, suggest a relationship between the availability of $\mathrm{C} 2$ and $\mathrm{C} 3$ compounds and $\mathrm{EB}$ and reproduction. However, since the described effects on reproduction are rather incoherent and studies on feeding extra $\mathrm{C} 3 \mathrm{com}-$ pounds and reproductive performance are scarce, further research could validate these suggestions. 


\section{Appendix}

Table II. Studies presented in Figures 3 to 6. Dietary treatment, no of cows, parity and DMI.

\begin{tabular}{|c|c|c|c|c|c|c|c|c|c|}
\hline & Dietary treatment & $\begin{array}{c}\text { Isocaloric }^{\mathrm{a}} \\
\mathrm{Y} / \mathrm{N}\end{array}$ & $\begin{array}{l}\text { Extra } \\
\text { nutrients } \\
(\% \text { DM) }\end{array}$ & $\begin{array}{c}\text { Extra } \\
\text { nutrients } \\
\left(\mathrm{kg} \cdot \mathrm{d}^{-1}\right)\end{array}$ & $\begin{array}{l}\text { Forage: } \\
\text { concentrate } \\
\text { (DM basis) }\end{array}$ & $\begin{array}{l}\text { Cows } \\
\text { (No.) }\end{array}$ & $\begin{array}{l}\text { Treatment } \\
\text { period } \\
\text { (DMI) }\end{array}$ & Parity & $\begin{array}{c}\text { DMI } \\
\left(\mathrm{kg} \mathrm{DM} \cdot \mathrm{d}^{-1}\right)\end{array}$ \\
\hline \multicolumn{10}{|c|}{ Lipogenic studies } \\
\hline \multirow[t]{3}{*}[8]{} & Control & & & & $50: 50$ & 45 & $0-84$ & $\geq 2$ & 23.1 \\
\hline & Tallow + yellow grease & $\mathrm{N}$ & 8.7 & 2.09 & & & & & 24.0 \\
\hline & Tallow + yellow grease & $\mathrm{N}$ & 17.4 & 3.74 & & & & & 21.5 \\
\hline \multirow[t]{2}{*}{ [9] } & Control & & & & $45: 55$ & 42 & $0-100$ & $\geq 2$ & 17.3 \\
\hline & $\begin{array}{l}\text { Prilled long chain satured fatty } \\
\text { acids }\end{array}$ & $\mathrm{N}$ & 2.5 & 0.39 & & & & & 15.5 \\
\hline \multirow[t]{6}{*}{ [62] } & Control, herd 1 & & & & $52: 48$ & 95 & $0-150$ & $\geq 2$ & \\
\hline & Long chain fatty acids, herd 1 & $\mathrm{~N}$ & & 0.50 & & & & & \\
\hline & Control, herd 2 & & & & & 47 & & & \\
\hline & Long chain fatty acids, herd 2 & $\mathrm{~N}$ & & 0.50 & & & & & \\
\hline & Control, herd 3 & & & & & 47 & & & \\
\hline & Long chain fatty acids, herd 3 & $\mathrm{~N}$ & & 0.50 & & & & & \\
\hline \multirow[t]{4}{*}[63,132]{} & Control, low protein & & & & $48: 52$ & 45 & $1-120$ & $\geq 2$ & 19.6 \\
\hline & Megalac $^{\mathrm{b}}$, low protein & $\mathrm{N}$ & 2.2 & 0.42 & & & & & 19.0 \\
\hline & Control, high protein & & & & 47:53 & & & & 19.4 \\
\hline & Megalac ${ }^{\mathrm{b}}$, high protein & $\mathrm{N}$ & 2.2 & 0.44 & & & & & 19.8 \\
\hline \multirow[t]{3}{*}{ [99] } & Control & & & & $46: 54$ & 48 & 21-119 & & 23.1 \\
\hline & Whole cotton seed (WCS) & $\mathrm{N}$ & & & & & & & 23.9 \\
\hline & WCS + Megalac ${ }^{b}$ & $\mathrm{~N}$ & 2.7 & 0.58 & & & & & 21.6 \\
\hline \multirow[t]{2}{*}{ [125] } & Control & & & & $45: 55$ & 90 & $0-75$ & $\geq 1$ & \\
\hline & Ca salts of long chain fatty acids & $\mathrm{N}$ & 3 & & & & & & \\
\hline \multirow[t]{3}{*}{ [76] } & Control & & & & $52: 48$ & 18 & 80 & $\geq 1$ & 20.0 \\
\hline & Ca salts of long-chain fatty acids & $\mathrm{Y}$ & 2.2 & & $65: 35$ & & & & 19.7 \\
\hline & Ca salts of long-chain fatty acids & $\mathrm{N}$ & 2.2 & & $52: 48$ & & & & 20.5 \\
\hline \multirow[t]{3}{*}{ [121] } & Control & & & & $84: 16$ & 201 & $0-70$ & $\geq 1$ & \\
\hline & Megalac plus ${ }^{\mathrm{d}}$ & $\mathrm{N}$ & 3 & 0.40 & & & & & \\
\hline & Megapro golde & $\mathrm{N}$ & 3 & 1.50 & & & & & \\
\hline \multirow[t]{2}{*}{ [65] } & Control & & & & $37: 63$ & 48 & $0-150$ & $\geq 2$ & 24.1 \\
\hline & Adolac ${ }^{\mathrm{c}}$ & $\mathrm{N}$ & 2.2 & 0.50 & & & & & 24.3 \\
\hline \multirow[t]{2}{*}{ [100] } & Control & & & & $34: 66$ & 36 & $0-150$ & $\geq 2$ & 24.0 \\
\hline & Adolac ${ }^{c}$ & $\mathrm{~N}$ & & 0.55 & & & & & 23.3 \\
\hline \multirow[t]{2}{*}{ [67] } & Soybean meal & & & & & 58 & $0-105$ & $\geq 2$ & 22.7 \\
\hline & Heat treated whole soybeans & $\mathrm{N}$ & & & & & & & 22.4 \\
\hline \multirow[t]{2}{*}{ [101] } & Control & & & & $45: 55$ & 47 & $-14-35$ & $\geq 1$ & 15.3 \\
\hline & Partially hydrogenated tallow & $\mathrm{N}$ & 2 & 0.40 & & & & & 15.5 \\
\hline \multirow[t]{2}{*}{ [102] } & Control & & & & $50: 50$ & 153 & $0-28$ & & 20.8 \\
\hline & Oilseeds (sunflower or soybean) & $\mathrm{N}$ & & & & & & & 20.4 \\
\hline [122] & Control & & & & 44:56 & 108 & $14-135$ & $\geq 1$ & \\
\hline
\end{tabular}


Table II. Continued.

\begin{tabular}{|c|c|c|c|c|c|c|c|c|c|}
\hline & Dietary treatment & $\begin{array}{l}\text { Isocaloric }^{\mathrm{a}} \\
\mathrm{Y} / \mathrm{N}\end{array}$ & $\begin{array}{c}\text { Extra } \\
\text { nutrients } \\
(\% \text { DM })\end{array}$ & $\begin{array}{c}\text { Extra } \\
\text { nutrients } \\
\left(\mathrm{kg} \cdot \mathrm{d}^{-1}\right)\end{array}$ & $\begin{array}{c}\text { Forage: } \\
\text { concentrate } \\
\text { (DM basis) }\end{array}$ & $\begin{array}{l}\text { Cows } \\
\text { (No.) }\end{array}$ & $\begin{array}{c}\text { Treatment } \\
\text { period } \\
(\mathrm{DMI})\end{array}$ & Parity & $\begin{array}{c}\text { DMI } \\
\left(\mathrm{kg} \mathrm{DM} \cdot \mathrm{d}^{-1}\right)\end{array}$ \\
\hline & Megalac ${ }^{b}$ & $\mathrm{~N}$ & & 0.50 & & & & & \\
\hline & Control & & & & & 48 & $14-63$ & & \\
\hline & Adolac $^{\mathrm{c}}$ & $\mathrm{N}$ & & 0.45 & & & & & \\
\hline \multirow[t]{2}{*}{ [126] } & Control & & & & $45: 55$ & 220 & $0-200$ & $\geq 1$ & \\
\hline & Megalac ${ }^{b}$ & $\mathrm{~N}$ & & 0.45 & & & & & \\
\hline \multirow[t]{4}{*}{ [82] } & Dry-rolled sorghum (DRS) $40 \%$ & & & & $34: 66$ & 36 & $5-96$ & $\geq 1$ & 21.6 \\
\hline & DRS + Megalac ${ }^{\mathrm{b}}$ & $\mathrm{Y}$ & 2.5 & & & & & & 17.8 \\
\hline & Steam-flaked sorghum (SFS) $40 \%$ & & & & & & & & 23.1 \\
\hline & SFS + Megalac ${ }^{b}$ & $\mathrm{Y}$ & 2.5 & & & & & & 19.5 \\
\hline \multirow[t]{5}{*}{ [103] } & Dry-rolled sorghum (DRS) & & & & $38: 62$ & 40 & $85 \pm 50$ & $\geq 1$ & 28.9 \\
\hline & DRS + Megalac ${ }^{\mathrm{b}}$ & $\mathrm{N}$ & 2.5 & & $37: 63$ & & & & 30.8 \\
\hline & Steam-flaked sorghum (SFS) & $\mathrm{Y}$ & & & $38: 62$ & & & & 26.7 \\
\hline & SFS + Megalac ${ }^{b}$ & $\mathrm{~N}$ & 2.5 & & $37: 63$ & & & & 26.1 \\
\hline & SFS + Megalac ${ }^{b}$ & $\mathrm{~N}$ & 5 & & $36: 64$ & & & & 26.8 \\
\hline \multirow[t]{2}{*}{ [105] } & Control & & & & $25: 75$ & 126 & $0-120$ & $\geq 2$ & 20.3 \\
\hline & Ca soaps of fatty acids & $\mathrm{N}$ & 2.6 & 0.53 & & & & & 20.2 \\
\hline \multirow[t]{2}{*}{ [104] } & Control & & & & $36: 64$ & 66 & $0-120$ & $\geq 2$ & 20.6 \\
\hline & Adolac ${ }^{c}$ & $\mathrm{~N}$ & 2.5 & 0.51 & & & & & 20.3 \\
\hline \multirow[t]{4}{*}{ [15] } & Control, low protein & & & & $49: 51$ & 34 & $14-84$ & & 24.2 \\
\hline & Tallow, low protein & $\mathrm{Y}$ & 3 & 0.72 & $65: 35$ & & & & 22.8 \\
\hline & Control, high protein & & & & $49: 51$ & 34 & & & 25.1 \\
\hline & Tallow, high protein & $\mathrm{N}$ & 3 & 0.68 & $65: 35$ & & & & 24.1 \\
\hline \multirow[t]{2}{*}{ [106] } & Control & & & & $39: 61$ & 14 & $0-84$ & $\geq 2$ & 25.9 \\
\hline & Megalac $^{b}$ & $\mathrm{~N}$ & 1.8 & 0.36 & & & & & 24.4 \\
\hline \multicolumn{10}{|c|}{ Glycogenic/lipogenic studies } \\
\hline [60] & Control & & & & $60: 40$ & 18 & 161 & $\geq 1$ & 21.0 \\
\hline & High fat (white grease) & $\mathrm{N}$ & 3 & & & & & & 20.1 \\
\hline & High concentrate level (corn silage) & $\mathrm{Y}$ & & & $40: 60$ & & & & 21.3 \\
\hline \multirow[t]{4}{*}{ [61] } & Low ground shelled corn level (LC) & & & & $45: 55$ & 8 & 52 & $\geq 2$ & 19.2 \\
\hline & $\begin{array}{l}\text { LC + prilled long chain satured } \\
\text { fatty acid }\end{array}$ & $\mathrm{N}$ & 3 & 0.621 & & & & & 20.7 \\
\hline & $\begin{array}{l}\text { High ground shelled corn level } \\
\text { (HC) }\end{array}$ & $\mathrm{N}$ & & & $70: 30$ & & & & 20.2 \\
\hline & $\begin{array}{l}\mathrm{HC}+\text { prilled long chain satured } \\
\text { fatty aci }\end{array}$ & $\mathrm{N}$ & 3 & 0.582 & & & & & 19.4 \\
\hline \multirow[t]{4}{*}{ [69] } & Control & & & & $70: 30$ & 4 & 60 & & 16.6 \\
\hline & VFA infusion (rumen) & $\mathrm{N}$ & & & & & & & 16.4 \\
\hline & Propionate infusion (rumen) & $\mathrm{N}$ & & & & & & & 16.6 \\
\hline & Glucose infusion (duodenum) & $\mathrm{N}$ & & & & & & & 16.5 \\
\hline [66] & Control & & & & $26: 74$ & 4 & $111 \pm 14$ & $\geq 2$ & 22.5 \\
\hline
\end{tabular}


Table II. Continued.

\begin{tabular}{|c|c|c|c|c|c|c|c|c|c|}
\hline & Dietary treatment & $\begin{array}{l}\text { Isocaloric }^{\mathrm{a}} \\
\mathrm{Y} / \mathrm{N}\end{array}$ & $\begin{array}{c}\text { Extra } \\
\text { nutrients } \\
(\% \text { DM })\end{array}$ & $\begin{array}{c}\text { Extra } \\
\text { nutrients } \\
\left(\mathrm{kg} \cdot \mathrm{d}^{-1}\right)\end{array}$ & $\begin{array}{l}\text { Forage: } \\
\text { concentrate } \\
\text { (DM basis) }\end{array}$ & $\begin{array}{l}\text { Cows } 7 \\
\text { (No.) }\end{array}$ & $\begin{array}{l}\text { Treatment } \\
\text { period } \\
\text { (DMI) }\end{array}$ & Parity & $\begin{array}{c}\text { DMI } \\
\left(\mathrm{kg} \mathrm{DM} \cdot \mathrm{d}^{-1}\right)\end{array}$ \\
\hline & Glucose infusion (abomasal) & $\mathrm{N}$ & & 1.00 & & & & & 22.4 \\
\hline & Tallow infusion (abomasal) & $\mathrm{N}$ & & 0.45 & & & & & 22.7 \\
\hline & Yellow grease inf. (abomasal) & $\mathrm{N}$ & & 0.45 & & & & & 21.5 \\
\hline \multirow[t]{4}{*}{ [68] } & High alfalfa silage (HA) & & & & $50: 50$ & 6 & 31 & $\geq 2$ & 24.8 \\
\hline & $\mathrm{HA}+$ tallow & $\mathrm{N}$ & 4 & & & & & & 22.9 \\
\hline & High corn silage (HC) & $\mathrm{Y}$ & & & $50: 50$ & & & & 22.6 \\
\hline & $\mathrm{HC}+$ tallow & $\mathrm{N}$ & 4 & & & & & & 21.4 \\
\hline \multirow[t]{2}{*}{ [78] } & High fat diet (tallow) & & & & $65: 35$ & 43 & $150 \pm 3$ & $\geq 2$ & 21.6 \\
\hline & High grain diet (ground corn) & $\mathrm{Y}$ & & & $50: 50$ & & & & 22.5 \\
\hline \multirow[t]{2}{*}{ [107] } & Tapioca & & & 2.00 & & 32 & $0-100$ & & 20.9 \\
\hline & Ca salts of palm and soya oil & $\mathrm{Y}$ & & & & & & & 20.2 \\
\hline \multicolumn{10}{|c|}{ Glycogenic studies } \\
\hline \multirow[t]{3}{*}{ [117] } & Control & & & & $86: 14$ & 4 & $60-90$ & $\geq 2$ & 18.5 \\
\hline & Glucose infusion (intravenous) & $\mathrm{N}$ & & 0.34 & & & & & 18.8 \\
\hline & Glucose infusion (intravenous) & $\mathrm{N}$ & & 0.74 & & & & & 19.7 \\
\hline \multirow[t]{3}{*}{ [124] } & Low concentrate level & & & 0.8 & & 90 & $0-350$ & $\geq 1$ & \\
\hline & Medium concentrate level & $\mathrm{N}$ & & 4 & & & & & \\
\hline & High concentrate level & $\mathrm{N}$ & & 7.2 & & & & & \\
\hline \multirow[t]{2}{*}{ [108] } & Molassed sugar beet feed & & & & $30: 70$ & 21 & & $\geq 2$ & 16.3 \\
\hline & Barley & $\mathrm{N}$ & & & & & & & 15.9 \\
\hline \multirow[t]{2}{*}[75,109]{} & High forage:concentrate ratio & & & & $84: 16$ & 46 & $5-100$ & $\geq 2$ & 20.9 \\
\hline & Low forage:concentrate ratio & $\mathrm{N}$ & & & $45: 55$ & & & & 24.8 \\
\hline \multirow[t]{2}{*}{ [50] } & Control & & & & & & & $2.8 \pm 0.2$ & \\
\hline & Extra starch & $\mathrm{Y}$ & 16 & & & & & & \\
\hline \multirow[t]{2}{*}{ [110] } & $\begin{array}{l}\text { Fibre concentrate (sugarbeetpulp, } \\
\text { Citruspulp, cottonseed) }\end{array}$ & & & & & 6 & $32 \pm 7$ & $\geq 2$ & 17.4 \\
\hline & $\begin{array}{l}\text { Starch concentrate (barley, wheat, } \\
\text { maize }\end{array}$ & $\mathrm{N}$ & & & & & & & 17.0 \\
\hline \multirow[t]{2}{*}{ [111] } & Control & & & & $50: 50$ & 6 & $49-133$ & $\geq 2$ & 18.8 \\
\hline & $\begin{array}{l}\text { High concentrate } \\
\text { ( } 74 \% \text { groundshelled corn, } \\
21 \% \text { soyabean meal) }\end{array}$ & & & & $17: 83$ & & & & 17.3 \\
\hline \multirow[t]{2}{*}{ [119] } & Control & & & & & 234 & $-13-12$ & $\geq 1$ & \\
\hline & Propylene glycol & $\mathrm{N}$ & & 1 & & & & & \\
\hline \multirow[t]{2}{*}{ [120] } & Control & & & & $48: 52$ & 4 & & & 19.9 \\
\hline & Glucose infusion (duodenum) & $\mathrm{Y}$ & & 2.25 & & & & & 16.5 \\
\hline \multirow[t]{2}{*}{ [112] } & Low starch $(0.5 \%)$ & & & & & $52: 48$ & 50 & $46 \pm 17$ & 16.6 \\
\hline & $\begin{array}{l}\text { High starch }(38.4 \%) \text { (wheat, } \\
\text { barley, maize) }\end{array}$ & $\mathrm{Y}$ & & & & & & & 16.4 \\
\hline [70] & Control & & & & & $50: 50$ & $424 \pm 2.1$ & $\geq 2$ & 22.5 \\
\hline
\end{tabular}


Table II. Continued.

\begin{tabular}{|c|c|c|c|c|c|c|c|c|c|}
\hline & Dietary treatment & $\begin{array}{l}\text { Isocaloric }^{\mathrm{a}} \\
\mathrm{Y} / \mathrm{N}\end{array}$ & $\begin{array}{c}\text { Extra } \\
\text { nutrients } \\
(\% \mathrm{DM})\end{array}$ & $\begin{array}{c}\text { Extra } \\
\text { nutrients } \\
\left(\mathrm{kg} \cdot \mathrm{d}^{-1}\right)\end{array}$ & $\begin{array}{l}\text { Forage: } \\
\text { concentrate } \\
\text { (DM basis) }\end{array}$ & $\begin{array}{l}\text { Cows } \\
\text { (No.) }\end{array}$ & $\begin{array}{l}\text { Treatment } \\
\text { period } \\
(\mathrm{DMI})\end{array}$ & Parity & $\begin{array}{c}\text { DMI } \\
\left(\mathrm{kg} \mathrm{DM} \cdot \mathrm{d}^{-1}\right)\end{array}$ \\
\hline & $\begin{array}{l}\text { Starch hydrolysate infusion } \\
\text { (abomasum }\end{array}$ & $\mathrm{N}$ & & 1.5 & & & & & 21.8 \\
\hline & $\begin{array}{l}\text { Starch hydrolysate infusion } \\
\text { (rumen) }\end{array}$ & $\mathrm{N}$ & & 1.5 & & & & & 21.7 \\
\hline \multirow[t]{2}{*}{ [71] } & Control & & & & $46: 54$ & 10 & $15-41$ & $\geq 2$ & 19.2 \\
\hline & Glucose infusion (intravenous) & $\mathrm{N}$ & & & & & & & 17.8 \\
\hline \multirow[t]{2}{*}{ [72] } & Control & & & & $40: 60$ & 75 & $-19-280$ & $\geq 1$ & 21.2 \\
\hline & High non-fiber carbohydrate (corn) & $\mathrm{N}$ & & & & & & & 21.3 \\
\hline \multirow[t]{2}{*}{ [77] } & Control & & & & $50: 50$ & 35 & $0-42$ & $\geq 1$ & 15.7 \\
\hline & Propylene glycol & $\mathrm{N}$ & & 0.50 & & & & & 15.4 \\
\hline \multirow[t]{2}{*}{ [113] } & Megalac $^{\mathrm{b}}+$ barley & & & 0.41 & $61: 39$ & 24 & $0-350$ & $\geq 2$ & 13.6 \\
\hline & $\begin{array}{l}\text { Megalac }{ }^{b}+\text { propionate }+ \text { propylene } \\
\text { glycol }\end{array}$ & & & 0.41 & & & & & 16.1 \\
\hline \multirow[t]{2}{*}{ [114] } & Control & & & & $50: 50$ & 20 & $-42-0$ & $\geq 2$ & 15.7 \\
\hline & Extra barley & $\mathrm{N}$ & & 0.80 & & & & & 16.0 \\
\hline \multirow[t]{5}{*}{ [115] } & Control & & & & $55: 45$ & 5 & $53 \pm 12$ & & 15.6 \\
\hline & Glucose infusion (duodenum) & $\mathrm{Y}$ & & $1.72^{\mathrm{d}}$ & & & & & 16.6 \\
\hline & Glucose infusion (duodenum) & $\mathrm{N}$ & & $3.45^{\mathrm{d}}$ & & & & & 16.7 \\
\hline & Propionate infusion (rumen) & $\mathrm{Y}$ & & $1.72^{\mathrm{d}}$ & & & & & 16.0 \\
\hline & Propionate infusion (rumen) & $\mathrm{N}$ & & $3.45^{\mathrm{d}}$ & & & & & 16.3 \\
\hline \multirow[t]{4}{*}{ [116] } & $\begin{array}{l}\text { Molassed sugar beet feed + } \\
\text { fishmeal }\end{array}$ & & & & $50: 50$ & 16 & $0-126$ & $\geq 2$ & 16.0 \\
\hline & Barley + fishmeal & $\mathrm{N}$ & & & & & & & 15.5 \\
\hline & $\begin{array}{l}\text { Molassed sugar beet feed }+ \\
\text { soyabean meal }\end{array}$ & & & & $48: 52$ & & & & 15.5 \\
\hline & Barley + soyabean meal & $\mathrm{N}$ & & & & & & & 16.0 \\
\hline
\end{tabular}

\section{REFERENCES}

[1] Van Arendonk JAM, Hovenier R, De Boer W Phenotypic and genetic association between fertility and production in dairy cows. Livest Prod Sci 1989, 21: 1-12.

[2] Pryce JE, Nielsen BL, Veerkamp RF, Simm G. Genotype and feeding system effects and interactions for health and fertility traits. Livest Prod Sci 1999, 57: 193-201.

[3] Westwood CT, Lean IJ, Garvin JK. Factors influencing fertility of Holstein dairy cows: a multivariate description. J Dairy Sci 2002, 85: 3225-3237.

[4] Rajala-Schultz PJ, Frazer GS. Reproductive performance in Ohio dairy herds in the 1990s. Anim Reprod Sci 2003, 76: 127-142.

[5] Nederlands Rundvee Syndicaat. Jaarstatistieken 2004: CR-Delta, Productdivisie NRS 2005, 80.

[6] Veerkamp RF, Oldenbroek JK, Van Der Gaast HJ, Van Der Werf JHJ. Genetic correlation between days until start of luteal activity and 
milk yield, energy balance, and live weights. J Dairy Sci 2000, 83: 577-583.

[7] Heuer C, Van Straalen WM, Schukken YH, Dirkzwager A, Noordhuizen JPTM. Prediction of energy balance in a high yielding dairy herd in early lactation: model development and precision. Livest Prod Sci 2000, 65: 91105.

[8] Beam SW, Butler WR. Energy balance and ovarian follicle development prior to first ovulation postpartum in dairy cows receiving three levels of dietary fat. Biol Reprod 1997, 56: $133-142$.

[9] Beam SW, Butler WR. Energy balance, metabolic hormones, and early postpartum follicular development in dairy cows fed prilled lipid. J Dairy Sci 1998, 81: 121-131.

[10] Butler WR, Everett RW, Coppock CE. The relationships between energy balance, milk production and ovulation in postpartum Holstein cows. J Anim Sci 1981, 53: 742-748.

[11] Canfield RW, Butler WR. Energy balance, first ovulation and the effects of naloxone on LH secretion in early postpartum dairy cows. J Anim Sci 1991, 69: 740-746.

[12] Harrison RO, Ford SP, Young JW, Conley AJ, Freeman AE. Increased milk production versus reproductive and energy status of high producing dairy cows. J Dairy Sci 1990, 73: 2749-2758.

[13] Lucy MC, Staples CR, Michel FM, Thatcher WW. Energy balance and size and number of ovarian follicles detected by ultrasonography in early postpartum dairy cows. J Dairy Sci 1991, 74: 473-482.

[14] Reksen O, Grohn YT, Havrevoll O, Bolstad T, Waldmann A, Ropstad E. Relationships among milk progesterone, concentrate allocation, energy balance, milk yield and conception rate in Norwegian cattle. Anim Reprod Sci 2002, 73: 169-184.

[15] Son J, Grant RJ, Larson LL. Effects of tallow and escape protein on lactional and reproductive performance. J Dairy Sci 1996, 79: 822830 .

[16] Spicer LJ, Tucker WB, Adams GD. Insulinelike growth factor-I in dairy cows: relationships among energy balance, body condition, ovarian activity, and estrus behaviour. J Dairy Sci 1990, 73: 929-937.

[17] Staples CR, Thatcher WW, Clark JH. Relationship between ovarian activity and energy status during the early postpartum period of high producing dairy cows. J Dairy Sci 1990 , 73: 938-947.
[18] Zurek E, Foxcroft GR, Kennelly JJ. Metabolic status and interval to first ovulation in postpartum dairy cows. J Dairy Sci 1995, 78 : 1909-1920.

[19] Grimard B, Humblot P, Ponter AA, Mialot JP, Sauvant D, Thibier M. Influence of postpartum energy restriction on energy status, plasma LH and oestradiol secretion and follicular development in suckled beef cows. J Reprod Fertil 1995, 104: 173-179.

[20] Wright IA, Rhind SM, Whyte TK, Smith AJ. Effects of body condition at calving and feeding level after calving on LH profiles and the duration of the post-partum anoestrus period in beef cows. Anim Prod 1992, 55: 41-46.

[21] Domecq JJ, Skidmore AL, Lloyd JW, Kaneene JB. Relationship between body condition scores and conception at first artificial insemination in a large dairy herd of high yielding Holstein cows. J Dairy Sci 1997, 80: 113-120.

[22] Butler WR, Smith RD. Interrelationships between energy balance and postpartum reproductive function in dairy cattle. J Dairy Sci 1989, 72: 767-783.

[23] Ferguson JD. Diet, production and reproduction in dairy cows. Anim Feed Sci Tech 1996, 59: $173-184$

[24] Beam SW, Butler WR. Effects of energy balance on follicular development and first ovulation in postpartum dairy cows. J Reprod Fertil 1999, 54: 411-424.

[25] Butler WR. Nutritional interactions with reproductive performance in dairy cattle. Anim Reprod Sci 2000, 60-61: 449-457.

[26] Gwazdauskas FC, Kendrick KW, Pryor AW, Bailey TL. Impact of follicular aspiration on folliculogenesis as influenced by dietary energy and stage of lactation. J Dairy Sci 2000, 83: 1625-1634.

[27] Boland MP, Lonergan P, O'Callaghan D. Effect of nutrition on endocrine parameters, ovarian physiology, and oocyte and embryo development. Theriogenology 2001, 55: 13231340.

[28] Britt JH. Impacts of early postpartum metabolism on follicular activity, cyclicity, fertility and embryonic death. In: Colenbrander B, Kemp B, Kruip TAM, van der Lende T (Eds.), Interaction of nutrition and reproduction, Den Haag, Nationale Raad voor Landbouwkundig Onderzoek, 1993, p 1-12.

[29] Butler WR. Energy balance relationships with follicular development, ovulation and fertility 
in postpartum dairy cows. Livest Prod Sci 2003, 83: 211-218.

[30] Friggens NC. Body lipid reserves and reproductive cycle: towards a better understanding. Livest Prod Sci 2003, 83: 219-236.

[31] Jorritsma R, Wensing T, Kruip TAM, Vos PLAM, Noordhuizen JPTM. Metabolic changes in early lactation and impaired reproductive performance in dairy cows. Vet Res 2003, 34: 11-26.

[32] Lucy MC, Savio JD, Badinga L, De La Sota RL, Thatcher WW. Factors that affect ovarian follicular dynamics in cattle. J Anim Sci 1992, 70: 3615-3626.

[33] Wade GN. Energy balance, effects on reproduction. In: Knobil E, Neill JD (Eds.), Encyclopedia of Reproduction, 1998, p 10911099 .

[34] Formigoni A, Trevisi E. Transition cow: interaction with fertility. Vet Res Commun 2003, 27 (Suppl): 143-152.

[35] Pryce JE, Royal MD, Garnsworthy PC, Mao IL. Fertility in the high producing dairy cow. Livest Prod Sci 2004, 86: 125-135.

[36] VandeHaar MJ, Sharma BK, Fogwell RL. Effect of dietary energy restriction on the expression of insulin-like growth factor-I in liver and corpus luteum of heifers. J Dairy Sci 1995, 78: 832-841.

[37] Yung MC, VandeHaar MJ, Fogwell RL, Sharma BK. Effect of energy balance and somatotropin on insulin-like growth factor I in serum and on weight and progesterone of corpus luteum in heifers. J Anim Sci 1996, 74: 2239-2244.

[38] Mackey DR, Sreenan JM, Roche JF, Diskin MD. Effect of acute nutritional restriction on incidence of anovulation and periovulatory estradiol and gonadotropin concentrations in beef heifers. Biol Reprod 1999, 61: 16011607.

[39] Villa-Godoy A, Hughes TL, Emery RS, Chapin LT, Fogwell RL. Association between energy balance and luteal function in lactating cows. J Dairy Sci 1988, 71: 1063-1072.

[40] Liefers SC, Te Pas MFW, Veerkamp RF, Van Der Lende T. Associations between leptin gene polymorphisms and production, live weight, energy balance, feed intake, and fertility in Holstein heifers. J Dairy Sci 2002, 85: 1633-1638.

[41] Reist M, Erdin DK, von Euw D, Tschumperlin KM, Leuenberger H, Hammon HM, Morel C, Philipona C, Zbinden Y, Kunzi N, Blum JW.
Postpartum reproductive function: association with energy, metabolic and endocrine status in high yielding dairy cows. Theriogenology 2003, 59: 1707-1723.

[42] Ingvartsen KL, Dewhurst RJ, Friggens NC. On the relationship between lactational performance and health: is it yield or metabolic imbalance that cause production diseases in dairy cattle? A position paper. Livest Prod Sci 2003, 83: 277-308.

[43] Collard BL, Boettcher PJ, Dekkers JCM, Petitclerc D, Schaeffer LR. Relationships between energy balance and health traits of dairy cattle in early lactation. J Dairy Sci 2000 , 83: 2683-2690.

[44] Grohn YT, Erb HN, McCulloch CE, Saloniemi HS. Epidemiology of metabolic disorders in dairy cattle: association among host characteristics, disease, and production. J Dairy Sci 1989, 72: 1876-1885.

[45] Heuer C, Schukken Y, Dobbelaar P. Postpartum body condition score and results from the first test day milk as predictors of disease, fertility, yield, and culling in commercial dairy herds. J Dairy Sci 1999, 82: 295-304.

[46] Webster J. Understanding the dairy cow. Oxford, Blackwell, 1993, p 374.

[47] Butler WR. Review: Effect of protein nutrition on ovarian and uterine physiology in dairy cattle. J Dairy Sci 1998, 81: 2533-2539.

[48] Chilliard Y. Dietary fat and adipose tissue metabolism in ruminants, pigs, and rodents: a review. J Dairy Sci 1993, 76: 3897-3931.

[49] Diskin MD, Mackey D, Roche JF, Sreenan JM. Effects of nutrition and metabolic status on circulating hormones and ovarian development in cattle. Anim Reprod Sci 2003, 78: 345-370.

[50] Gong JG. Influence of metabolic hormones and nutrition on ovarian follicle development in cattle: practical implications. Domest Anim Endocrinol 2002, 23: 229-241.

[51] Grummer RR, Carroll DJ. A review of lipoprotein cholesterol metabolism: importance to ovarian function. J Anim Sci 1988, 66: 31603173.

[52] O'Callaghan D, Boland MP. Nutritional effects on ovulation, embryo development and the establishment of pregnancy in ruminants. Anim Sci 1999, 68: 299-314.

[53] Robinson JJ. Nutrition and reproduction. Anim Reprod Sci 1996, 42: 25-34.

[54] Staples CR, Burke JM, Thatcher WW. Influence of supplemental fats on reproductive tissues and performance of lactating cows. J Dairy Sci 1998, 81: 856-871. 
[55] Grummer RR. Etiology of lipid-related metabolic disorders in periparturient dairy cows. $\mathbf{J}$ Dairy Sci 1993, 76: 3882-3896.

[56] Grummer RR, Carroll DJ. Effects of dietary fat on metabolic disorders and reproductive performance of dairy cattle. J Anim Sci 1991, 69: 3838-3852.

[57] Butler ST, Marr AL, Pelton SH, Lucy MC, Butler WR. Insulin restores GH responsiveness during lactation-induced negative energy balance in dairy cattle: effects on expression of IGF-I and GH receptor 1A. J Endocrinol 2003, 176: 205-217.

[58] Veenhuizen JJ, Drackley JK, Richard MJ, Sanderson TP, Miller LD, Young JW. Metabolic changes in blood and liver during development and early treatment of experimental fatty liver and ketosis in cows. J Dairy Sci 1991, 74: 4238-4253.

[59] Jorritsma R. Negative energy balance in dairy cows as related to fertility. $\mathrm{PhD}$ thesis, Utrecht, The Netherlands, Utrecht University, 2003, p 159.

[60] Drackley JK, Cicela TM, LaCount DW. Responses of primiparous and multiparous Holstein cows to additional energy from fat or concentrate during summer. J Dairy Sci 2003, 86: $1306-1314$

[61] Grum DE, Drackley JK, Hansen LR, Cremin JD. Production, digestion, and hepatic lipid metabolism of dairy cows fed increased energy from fat or concentrate. J Dairy Sci 1996, 79: 1836-1849.

[62] Ferguson JD, Sklan D, Chalupa WV, Kronfeld DS. Effects of hard fats on in vitro and in vivo rumen fermentation, milk production and reproduction in dairy cows. J Dairy Sci 1990, 73: 2864-2879.

[63] Garcia-Bojalil CM, Staples CR, Risco CA, Savio JD, Thatcher WW. Protein degradability and calcium salts of long-chain fatty acids in the diets of lactating dairy cows: productive responses. J Dairy Sci 1998, 81: 1374-1384.

[64] Lucy MC, De La Sota RL, Staples CR, Thatcher WW. Ovarian follicular populations in lactating dairy cows treated with recombinant bovine somatotropin (sometribove) or saline and fed diets differing in fat content and energy. J Dairy Sci 1993, 76: 1014-1027.

[65] Moallem U, Kaim M, Folman Y, Sklan D. Effect of calcium soaps of fatty acids and administration of somatotropin in early lactation on productive and reproductive perform- ance of high producing dairy cows. J Dairy Sci 1997, 80: 2127-2136.

[66] Oldick BS, Staples CR, Thatcher WW, Gyawu P. Abosomal infusion of glucose and fat. Effect on digestion, production, and ovarian and uterine functions of cows. J Dairy Sci 1997, 80: 1315-1328.

[67] Ruegsegger GJ, Schultz LH. Response of high producing dairy cows in early lactation to the feeding of heat-treated whole soybeans. J Dairy Sci 1985, 68: 3272-3279.

[68] Ruppert LD, Drackley JK, Bremmer DR, Clark JH. Effects of tallow in diets based on corn silage or alfalfa silage on digestion and nutrient use by lactating dairy cows. J Dairy Sci 2003, 86: 593-609.

[69] Hurtaud C, Rulquin H, Verite R. Effects of level and type of energy source (volatile fatty acids or glucose) on milk yield, composition and coagulating properties in dairy cows. Reprod Nutr Dev 1998, 38: 315-330.

[70] Knowlton KF, Dawson TE, Glenn BP, Huntington GB, Erdman RA. Glucose metabolism and milk yield of cows infused abomasally or ruminally with starch. J Dairy Sci 1998, 81: 3248-3258.

[71] Leonard M, Block E. Effects of nutrition and hormonal profile of long-term infusions of glucose or insulin plus glucose in cows treated with recombinant bovine somatotropin before peak milk yield. J Dairy Sci 1997, 80: 127143.

[72] Minor DJ, Trower SL, Strang BD, Shaver RD, Grummer RR. Effects of nonfiber carbohydrate and niacin on periparturient metabolic status and lactation of dairy cows. J Dairy Sci 1998, 81: 189-200.

[73] Ramanzin M, Bailoni L, Schiavon S, Bittante G. Effect of monensin on milk production and efficiency of dairy cows fed two diets differing in forage to concentrate ratios. J Dairy Sci 1997, 80: 1136-1142.

[74] Eastridge ML, Cunningham MD, Patterson JA. Effect of dietary energy source and concentration on performance of dairy cows during early lactation. J Dairy Sci 1988, 71: 2959-2966.

[75] Jerred MJ, Carroll DJ, Combs DK, Grummer RR. Effect of fat supplementation and immature alfalfa to concentrate ratio on lactation performance of dairy cattle. J Dairy Sci 1990, 73: 2842-2854.

[76] Aiello RJ, Kenna TM, Herbein JH. Hepatic gluconeogenic and ketogenic interrelationships in the lactating cow. J Dairy Sci 1984, 67: 1707-1715. 
[77] Miyoshi S, Pate JL, Palmquist DL. Effects of propylene glycol drenching on energy balance, plasma glucose, plasma insulin, ovarian function and conception in dairy cows. Anim Reprod Sci 2001, 68: 29-43.

[78] Vazquez-Anon M, Bertics SJ, Grummer RR. The effect of dietary energy source during mid to late lactation on liver triglycerides and lactation performance. J Dairy Sci 1997, 80: 2504-2512.

[79] Thomas MG, Bao B, Williams GL. Dietary fats varying in their fatty acid composition differentially influence follicular growth in cows fed isoenergetic diets. J Anim Sci 1997, 75: 2512-2519.

[80] Doreau M, Chilliard Y. Digestion and metabolism of dietary fat in farm animals. Br J Nutr 1997, 78: S15-S35.

[81] Santos FAP, Huber JT, Theurer CB, Nussio LG, Tarazon M, Fish D. Effects of grain processing and bovine somatotropin on metabolism and ovarian activity of dairy cows during early lactation. J Dairy Sci 2000, 83: 1004-1015.

[82] Simas JM, Huber JT, Wu Z, Chen KH, Chan SC, Theurer CB, Swingle RS. Influence of steam-flaked sorghum grain and supplemental fat on performance of dairy cows in early lactation. J Dairy Sci 1995, 78: 1526-1533.

[83] Lefcourt AM, Huntington JB, Akers RM, Wood DL, Bitman J. Circadian and ultradian rhythms of body temperature and peripheral concentrations of insulin and nitrogen in lactating dairy cows. Domest Anim Endocrinol 1999, 16: 41-55.

[84] Cisse M, Chilliard Y, Coxam V, Davicco MJ, Remond B. Slow release somatotropin in dairy heifers and cows fed two levels of energy concentrate. 2. Plasma hormones and metabolites. J Dairy Sci 1991, 74: 1382-1394.

[85] Marie M, Findlay PA, Thomas L, Adam CL. Daily patterns of plasma leptin in sheep: effects of photoperiod and food intake. J Endocrinol 2001, 170: 277-286.

[86] Owens FN, Secrist DS, Hill WJ, Gill DR. Acidosis in cattle: a review. J Anim Sci 1998, 76: 275-286.

[87] Nocek JE. Bovine acidosis: implications on laminitis. J Dairy Sci 1997, 80: 1005-1028.

[88] Keady TWJ, Mayne CS. The effects of concentrate energy source on feed intake and rumen fermentation parameters of dairy cows offered a range of grass silages. Anim Feed Sci Tech 2001, 90: 117-129.

[89] Reid IM. Incidence and severity of fatty liver in dairy cows. Vet Rec 1980, 107: 281.

[90] Studer VA, Grummer RR, Bertics SJ, Reynolds CK. Effect of prepartum propylene glycol administration on periparturient fatty liver in dairy cows. J Dairy Sci 1993, 76: 2931-2939.

[91] Grummer RR, Luck ML, Barmore JA. Rumen fermentation and lactation performance of cows fed roasted soybeans and tallow. J Dairy Sci 1993, 76: 2674-2681.

[92] Kronfeld DS. Major metabolic determinants of milk volume, mammary efficiency, and spontaneous ketosis in dairy cows. J Dairy Sci 1982, 65: 2204-2212.

[93] Drackley JK. Physiological and pathological adaptations in dairy cows that may increase susceptibility to periparturient diseases. In: Proceedings 54th European Association of Animal Production Meeting, Rome, Italy, 2003, p 1-16.

[94] Suriyasathaporn W, Daemen AJJM, Noordhuizen-Stassen EN, Dieleman SJ, Nielen M, Schukken YH. Beta-hydroxybutyrate levels in peripheral blood and ketone bodies supplemented in culture media affect the in vitro chemotaxis of bovine leukocytes. Vet Immunol Immunopathol 1999, 68: 177186.

[95] Franklin ST, Young JW, Nonnecke BJ. Effects of ketones, acetate, butyrate, and glucose on bovine lymphocyte proliferation. J Dairy Sci 1991, 74: 2507-2514.

[96] Targowski SP, Klucinski DVM. Reduction in mitogenic response of bovine lymphocytes by ketone bodies. Am J Vet Res 1983, 44: 828830.

[97] Nonnecke BJ, Franklin ST, Young JW. Effects of ketones, acetate, and glucose on in vitro immunoglobulin secretion by bovine lymphocytes. J Dairy Sci 1992, 75: 982-990.

[98] Kremer WDJ, Noordhuizen-Stassen EN, Grommers FJ, Schukken YH, Heeringa R, Brand A. Severity of experimental Escherichia coli mastitis in ketonemic and nonketonemic cows. J Dairy Sci 1993, 76: 34283436.

[99] Harrison JH, Kincaid RL, McNamara JP, Waltner S, MLoney KA, Riley RE, Cronrath JD. Effect of whole cottonseeds and calcium salts of long-chain fatty acids on performance of lactating dairy cows. J Dairy Sci 1995, 78 : 181-193. 
[100] Moallem U, Folman Y, Bor A, Arav A, Sklan D. Effect of calcium soaps of fatty acids and administration of somatotropin on milk production, preovulatory follicular development, and plasma and follicular fluid lipid composition in high yielding dairy cows. J Dairy Sci 1999, 82: 2358-2368.

[101] Salfer JA, Linn JG, Otterby DE, Hansen WP, Johson DG. Early lactation responses of Holstein cows fed a rumen-inert fat prepartum, postpartum, or both. J Dairy Sci 1995, 78: 368-377.

[102] Schingoethe DJ, Casper DP. Total lactational response to added fat during early lactation. J Dairy Sci 1991, 74: 2617-2622.

[103] Simas JM, Huber JT, Theurer CB, Chen KH, Santos FAP, Wu Z. Influence of sorghum grain processing on performance and nutrient digestibilities in dairy cows fed varying concentrations of fat. J Dairy Sci 1998, 81: 19661971.

[104] Sklan D, Kaim M, Moallem U, Folman Y. Effect of dietary calcium soaps on milk yield, body weight, reproductive hormones, and fertility in first parity and older cows. J Dairy Sci 1994, 77: 1652-1660.

[105] Sklan D, Moallem U, Folman Y. Effect of feeding calcium soaps of fatty acids on production and reproduction responses in high producing lactating cows. J Dairy Sci 1991, 74: 510-517.

[106] Spicer LJ, Vernon RK, Tucker WB, Wetteman RP, Hogue JF, Adams GD. Effects of inert fat on energy balance, plasma concentrations of hormones, and reproduction in dairy cows. $\mathbf{J}$ Dairy Sci 1993, 76: 2664-2673.

[107] Voigt J, Gaafar K, Hagemeister H, Kanitz W, Precht D. Fat vs. starch as energy sources in diets for high yielding lactating dairy cows. In: Progress in research on energy and protein metabolism, Rostock, Germany, 2003, p 445448.

[108] Beever DE, Cammell SB, Sutton JD, Spooner MC, Haines MJ, Harland JI. Effect of concentrate type on energy utilization in lactating dairy cows. In: Energy metabolism of farm animals, Lunteren, The Netherlands, 1989, p 33-36.

[109] Carroll DJ, Jerred MJ, Grummer RR, Combs DK, Pierson RA, Hauser ER. Effects of fat supplementation and immature alfalfa to concentrate ratio on plasma progesterone, energy balance, and reproductive traits of dairy cattle. J Dairy Sci 1990, 73: 2855-2863.

[110] Gordon FJ, Porter MG, Mayne CS, Unsworth EF, Kilpatrick DJ. Effect of forage digesti- bility and type of concentrate on nutrient utilization by lactating dairy cattle. J Dairy Res 1995, 62: 15-27.

[111] Grummer RR, Davis CL. Plasma concentration and lipid composition of lipoproteins in lactating dairy cows fed control and high grain diets. J Dairy Sci 1984, 67: 2894-2901.

[112] Keady TWJ, Mayne CS. The effects of concentrate energy source on silage feeding behaviour and energy utilization by lactating dairy cows offered grass silages with differing intake characteristics. Anim Sci 1998, 67: 225-236.

[113] Patton RS, Sorenson CE, Hippen AR. Effects of dietary glucogenic precursors and fat on feed intake and carbohydrate status of transition dairy cows. J Dairy Sci 2004, 87: 2122 2129.

[114] Pushpakumara PGA, Gardner NH, Reynolds CK, Beever DE, Wathes DC. Relationships between transition period diet, metabolic parameters and fertility in lactating dairy cows. Theriogenology 2003, 60: 1165-1185.

[115] Rigout S, Hurtaud C, Lemosquet S, Bach A, Rulquin H. Lactational effect of propionic acid and duodenal glucose in cows. J Dairy Sci 2003, 86: 243-253.

[116] Sutton JD, Cammell SB, Beever DE, Haines MJ, Spooner MC, Harland JI. The effect of energy and protein sources on energy and nitrogen balances in Friesian cows in early lactation. In: Energy metabolism of farm animals, EAAP publication, Kartause Ittingen, Switzerland, 1991, p 288-291.

[117] Amaral DM, Veenhuizen JJ, Drackley JK, Cooley MH, McGillard AD, Young JW. Metabolism of proprionate, glucose, and carbon dioxide as affected by exogenous glucose in dairy cows at energy equilibrium. $\mathrm{J}$ Dairy Sci 1990, 73: 1244-1254.

[118] Gong JG, Lee WJ, Garnsworthy PC, Webb R. Effect of dietary-induced increases in circulating insulin concentrations during the early postpartum period on reproductive function in dairy cows. Reproduction 2002, 123:419427.

[119] Hoedemaker M, Prange D, Zerbe H, Frank J, Daxenberger A, Meyer HHD. Peripartal propylene glycol supplementation and metabolism, animal health, fertility, and production in dairy cows. J Dairy Sci 2004, 87: 21362145.

[120] Hurtaud C, Lemosquet S, Rulquin H. Effect of graded duodenal infusions of glucose on yield and composition of milk from dairy 
cows. 2. Diets based on grass silage. J Dairy Sci 2000, 83: 2952-2962.

[121] McNamara S, Butler T, Ryan DP, Mee JF, Dillon P, O'Mara FP, Butler ST, Anglesey D, Rath M, Murphy JJ. Effect of offering rumenprotected fat supplements and performance in spring-calving Holstein-Friesian cows. Anim Reprod Sci 2003, 79: 45-56.

[122] Schneider P, Sklan D, Chalupa WV, Kronfeld DS. Feeding calcium salts of fatty acids to lactating cows. J Dairy Sci 1988, 71:21432150.

[123] Sklan D, Bogin E, Avidar Y, Gur-Arie S. Feeding calcium soaps of fatty acids on production and reproductive responses in high producing lactating cows. J Dairy Res 1989 , 56: 675 .

[124] Armstrong JD, Goodall EA, Gordon FJ, Rice DA, McCaughey WJ. The effects of levels of concentrate offered and inclusion of maize gluten or fish meal in the concentrate on reproductive performance and blood parameters of dairy cows. Anim Prod 1990, 50: 110.

[125] Lucy MC, Staples CR, Thatcher WW, Erickson PS, Cleale RM, Firkins JL, Clark JH, Murphy MR, Brodie BO. Influence of diet composition, dry-matter intake, milk production and energy balance on time of post-partum ovulation and fertility in dairy cows. Anim Prod 1992, 54: 323-331.

[126] Scott TA, Shaver RD, Zepeda L, Yandell B, Smith TR. Effects of rumen-inert fat on lactation, reproduction, and health of high producing Holstein herds. J Dairy Sci 1995, 78: 2435-2451.

[127] Robinson JJ, Pushpakumara PGA, Cheng Z, Peters AR, Abayasekara DRE, Wathes DC. Effects of dietary polyunsaturated fatty acids on ovarian and uterine function. Reproduction 2002, 124: 119-131.

[128] Lucy MC, Staples CR, Michel FM, Thatcher WW, Bolt DJ. Effect of feeding calcium soaps to early postpartum dairy cows on plasma prostaglandin F2 $\alpha$, luteinizing hormone, and follicular growth. J Dairy Sci 1991, 74: 483-489.

[129] Lammoglia MA, Willard ST, Hallford DM, Randel RD. Effects of dietary fat on follicular development and circulating concentrations of lipids, insulin, progesterone, estradiol-17ß, 13,14-dihydro-15-keto-prostaglandin $\mathrm{F} 2 \alpha$, and growth hormone in estrous cyclic Brahman cows. J Anim Sci 1997, 75: 1591-1600.
[130] Petit HV, Dewhurst RJ, Proulx JG, Khalid M, Haresign W, Twagiramungu H. Milk production, milk composition, and different reproductive function of dairy cows fed different fats. Can J Anim Sci 2001, 81: 263-271.

[131] Sanz A, Bernues A, Villalba D, Casasus I, Revilla R. Influence of management and nutrition on postpartum interval in Brown Swiss and Pirenaica cows. Livest Prod Sci 2004, 86: 179-191.

[132] Garcia-Bojalil CM, Staples CR, Risco CA, Savio JD, Thatcher WW. Protein degradability and calcium salts in the diets of lactating dairy cows: reproductive responses. J Dairy Sci 1998, 81: 1385-1395.

[133] Nolan R, O'Callaghan D, Duby RT, Lonergan $\mathrm{P}$, Boland MP. The influence of short-term nutrient changes on follicle growth and embryo production following superovulation in beef heifers. Theriogenology 1998, 50: 1263-1274.

[134] Rabie AR, Macmillan KL, Schwarzenberger F. The effect of level of feed intake on progesterone clearnace rate by measuring faecal progesterone metabolites in grazing dairy cows. Anim Reprod Sci 2001, 67: 205-214.

[135] Butler WR. Inter-relationships between energy balance and postpartum reproduction in dairy cattle. In: Colenbrander B, Kemp B, Kruip TAM, van der Lende T (Eds.), Interaction of nutrition and reproduction, Den Haag, 1993, p 1-14.

[136] Lucy MC, Beck J, Staples CR, Head HH, De La Sota RL, Thatcher WW. Follicular dynamics, plasma metabolites, hormones and insulin-like growth factor I (IGF-I) in lactating cows with positive or negative energy balance during the preovulatory period. Reprod Nutr Dev 1992, 32: 331-341.

[137] Villa-Godoy A, Hughes TL, Emery RS, Enright WJ, Ealy AD, Zinn S, Fogwell RL. Energy balance and body condition influence luteal function Holstein heifers. Domest Anim Endocrinol 1990, 7: 135-148.

[138] Walters AH, Pryor AW, Bailey TL, Pearson RE, Gwazdauskas FC. Milk yield, energy balance, hormone, follicular and oocyte measures in early and mid-lactation Holstein cows. Theriogenology 2002, 57: 949-961.

[139] Spicer LJ, Alonso J, Chamberlain S. Effects of thyroid hormones on bovine granulosa and theca cell function in vitro; dependence on insulin and gonadotropins. J Dairy Sci 2001, 84: 1069-1076. 